\title{
Meis1 Coordinates Cerebellar Granule Cell Development by Regulating Pax6 Transcription, BMP Signaling and Atoh1 Degradation
}

\author{
Tomoo Owa, ${ }^{1}$ Shinichiro Taya, ${ }^{1}$ Satoshi Miyashita, ${ }^{1,2}$ Mariko Yamashita, ${ }^{1,3}$ Toma Adachi, ${ }^{1,4}$ Koyo Yamada, ${ }^{1,3}$ \\ Miwa Yokoyama, ${ }^{1,3}$ Shogo Aida, ${ }^{1,5}$ ФTomoki Nishioka, ${ }^{6}$ Yukiko U. Inoue, ${ }^{1}$ (D) Ro Goitsuka, ${ }^{7}$ Takuro Nakamura, ${ }^{8}$ \\ Takayoshi Inoue, ${ }^{1}$ Kozo Kaibuchi, ${ }^{6}$ and Mikio Hoshino ${ }^{1}$ \\ ${ }^{1}$ Department of Biochemistry and Cellular Biology, National Institute of Neuroscience, National Center of Neurology and Psychiatry, Tokyo 187-8502, \\ Japan, ${ }^{2}$ Department of Electrical Engineering and Bioscience, Waseda University, Shinjuku, Tokyo 169-8555, Japan, ${ }^{3}$ Department of NCNP Brain Physiology \\ and Pathology, Graduate School of Medical and Dental Sciences, Tokyo Medical and Dental University, Tokyo, Japan, ${ }^{4}$ Department of Life Science and \\ Medical Bioscience, Faculty of Science and Engineering, Waseda University, Tokyo 162-8480, Japan, ${ }^{5}$ Department of Biomolecular Science, Faculty of \\ Science, Toho University, Miyama, Funabashi, Chiba, Japan, ${ }^{\circ}$ Department of Cell Pharmacology, Nagoya University Graduate School of Medicine, Showa- \\ ku, Nagoya 466-8550, Japan, ${ }^{7}$ Division of Development and Aging, Research Institute for Biomedical Science, Tokyo University of Science, Noda, Chiba, \\ Japan, and ${ }^{8}$ Division of Carcinogenesis, Cancer Institute, Japanese Foundation for Cancer Research, Koto, Tokyo, Japan
}

Cerebellar granule cell precursors (GCPs) and granule cells (GCs) represent good models to study neuronal development. Here, we report that the transcription factor myeloid ectopic viral integration site 1 homolog (Meis1) plays pivotal roles in the regulation of mouse GC development. We found that Meis1 is expressed in GC lineage cells and astrocytes in the cerebellum during development. Targeted disruption of the Meis1 gene specifically in the GC lineage resulted in smaller cerebella with disorganized lobules. Knock-down/knock-out (KO) experiments for Meis1 and in vitro assays showed that Meis1 binds to an upstream sequence of Pax6 to enhance its transcription in GCPs/GCs and also suggested that the Meis1-Pax6 cascade regulates morphology of GCPs/GCs during development. In the conditional KO (cKO) cerebella, many Atoh1-positive GCPs were observed ectopically in the inner external granule layer (EGL) and a similar phenomenon was observed in cultured cerebellar slices treated with a bone morphogenic protein (BMP) inhibitor. Furthermore, expression of Smad proteins and Smad phosphorylation were severely reduced in the cKO cerebella and Meis1-knock-down GCPs cerebella. Reduction of phosphorylated Smad was also observed in cerebellar slices electroporated with a Pax6 knock-down vector. Because it is known that BMP signaling induces Atoh1 degradation in GCPs, these findings suggest that the Meis1-Pax6 pathway increases the expression of Smad proteins to upregulate BMP signaling, leading to degradation of Atohl in the inner EGL, which contributes to differentiation from GCPs to GCs. Therefore, this work reveals crucial functions of Meis1 in GC development and gives insights into the general understanding of the molecular machinery underlying neural differentiation from neural progenitors.

Key words: Atoh1; cerebellum; developmental biology; differentiation; granule cell; Meis1

Significance Statement

We report that myeloid ectopic viral integration site 1 homolog (Meis1) plays pivotal roles in the regulation of mouse granule cell (GC) development. Here, we show Meis1 is expressed in GC precursors (GCPs) and GCs during development. Our knock-down and conditional knock-out (cK0) experiments and in vitro assays revealed that Meis1 is required for proper cerebellar structure formation and for Pax6 transcription in GCPs and GCs. The Meis1-Pax6 cascade regulates the morphology of GCs. In the cKO cerebella, Smad proteins and bone morphogenic protein (BMP) signaling are severely reduced and Atoh1-expressing GCPs are ectopically detected in the inner external granule layer. These findings suggest that Meis1 regulates degradation of Atohl via BMP signaling, contributing to GC differentiation in the inner EGL, and should provide understanding into GC development. 


\section{Introduction}

Cerebellar granule cell precursors (GCPs) are generated from the rhombic lip (RL) and migrate circumferentially along the surface of the cerebellar primordium to form the external granule layer (EGL) at the middle to late embryonic stages. They actively proliferate in the outer EGL and then exit from the cell cycle to become granule cells (GCs) in the inner EGL at the late embryonic and early postnatal stages. GCs then start to migrate into the molecular layer (ML) and eventually reside in the internal granular layer (IGL) (Komuro and Yacubova, 2003). During and after migration, maturation of GCs proceeds and they extend their processes to form parallel fibers in the ML (Sotelo, 2004; Espinosa and Luo, 2008).

Numerous studies have reported many molecules, including transcription factors and environmental cues, that are involved in GC development (Wang and Zoghbi, 2001; Komuro and Yacubova, 2003; Butts et al., 2011). Atoh1 is a well known key transcription factor that determines cell fates in the GC lineage and proliferation of GCPs (Flora et al., 2009). Dysregulated overexpression of Atohl can cause medulloblastoma (Ayrault et al., 2010). Bone morphogenic protein (BMP) signaling induces differentiation of GCPs into GCs (Zhao et al., 2008) and Shh can enhance Atoh1 expression (Forget et al., 2014). Pax6 is also a key transcription factor that controls the migration and differentiation of GCs and its involvement in GC differentiation was also reported (Lorenz et al., 2011; Swanson et al., 2011). However, the overall machinery that regulates these processes of GC development is still unclear.

Myeloid ectopic viral integration site 1 homolog (Meis1) is a transcription factor of the three amino acid loop extension (TALE) protein family (Hisa et al., 2004; Azcoitia et al., 2005). Meis1 has been reported to maintain the undifferentiated state of progenitor cells, including retinal progenitor cells (Heine et al., 2008), olfactory epithelial cells (Tucker et al., 2010), postnatal thymic epithelial cells (Hirayama et al., 2014), and hematopoietic stem cells (Hisa et al., 2004; Azcoitia et al., 2005). Misexpression of this gene has been linked to tumorigenesis; for example, acute myeloid leukemia, acute lymphoblastic leukemia (Lawrence et al., 1999; Imamura et al., 2002), and neuroblastoma (Spieker et al., 2001; Geerts et al., 2003). In the developing nervous system, Meis1 is expressed in the forebrain (Barber et al., 2013), the midbrain (Heine et al., 2008; Erickson et al., 2010), the hindbrain (Stedman et al., 2009), and the deep nuclei and EGL of the cerebellum (Morales and Hatten, 2006). However, the function of Meis1 in the nervous system during neural development remains unclear because targeted disruption of Meis 1 results in lethality at the mid-embryonic stages.

Received June 5, 2017; revised Dec. 12, 2017; accepted Dec. 19, 2017

Author contributions: T.0., S.T., and M.H. designed research; T.O., S.T., S.M., M. Yamashita, T.A., K.Y., M. Yokoyama, S.A., and T. Nishioka performed research;Y.U.I., R.G., T. Nakamura, T.I., and K.K. contributed unpublished reagents/analytic tools; T.O., S.T., S.M., and T. Nishioka analyzed data; T.O. and M.H. wrote the paper.

This work was supported by Grants-in-Aid for Scientific Research (Grant 15H04268 to M.H.), Challenging Exploratory Research (Grant 15K14337 to M.H.), KAKENHI (17K07126 to S.T.), and Innovative Areas (Grants 15 H01304 and $16 \mathrm{H} 06528$ to M.H.) from MEXT; the SRPBS from AMED (16dm0107085h0001), Naito Foundation, Takeda Foundation, Uehara Foundation, Princess Takamatsu Cancer Research Fund, an Intramural Research Grant (Grants 27-7 and 28-4 to M.H.), The Japan Epilepsy Research Foundation for Neurological and Psychiatric Disorders of the National Center of Neurology and Psychiatry (S.T.). We thank Dr. Ruth Yu (St Jude Children's Research Hospital) for comments on the manuscript.

The authors declare no competing financial interests.

Correspondence should be addressed to either Mikio Hoshino or Shinichiro Taya, Department of Biochemistry and Cellular Biology, National Institute of Neuroscience, NCNP, 4-1-1 Ogawa-Higashi Kodaira Tokyo 187-8502, Japan, E-mail: hoshino@ncnp.go.jp or s-taya@ncnp.go.jp.

DOI:10.1523/JNEUROSCI.1545-17.2017

Copyright $\odot 2018$ the authors $\quad 0270-6474 / 18 / 381278-18 \$ 15.00 / 0$
In this study, we found that Meis1 is constitutively expressed in all cells in the GC lineage, from GCPs in the EGL to GCs in the IGL during development, but its expression is lost after all cerebellar cells reach their appropriate positions. This led us to consider the possibility that Meis1 is involved in the development of cerebellar GCs at various developmental stages. Therefore, in this study, we investigated the function of Meis1 in GC development by in vitro and in vivo experiments including knock-down and conditional knock-out analyses. We found that Meis1 activates Pax6 expression in GCPs/GCs. The Meis1-Pax6 pathway regulates the cell cycle exit of GCPs, which is probably involved in the cessation of Atoh1 expression in the inner EGL through enhancing BMP-dependent Atoh1 degradation. The Meis1-Pax6 pathway also participates in maturation of GCs and formation of parallel fibers that may contribute to proper folial formation and overall cerebellar structure. This study should contribute to our understanding of GC development and further reveal insights into the molecular machinery underlying neuron development from their precursors, as well as oncogenesis of medulloblastoma, a cerebellar tumor.

\section{Materials and Methods}

Animals. All animal experiments in this study were approved by the Animal Care and Use Committee of the National Institute of Neuroscience, National Center of Neurology and Psychiatry (Tokyo, Japan; project 2008005). The Tg-Atoh1-Cre and Meisl flox mouse lines have been described previously (Fujiyama et al., 2009; Ariki et al., 2014). Control and mutant mice of both sexes were used in this study.

Plasmids. The cDNA of Meis1 (GenBank accession number NM_010789) was inserted into pEF-BOS-myc, pGEX-4T vector (GE Healthcare) and pEF-BOS-GST vectors (gifts from K. Kaibuchi, Nagoya University, Nagoya, Japan) to generate pEF-BOS-myc-Meis1 plasmids and pEF-BOSGST-Meis1. The cDNA of the Meis1 fragment was generated by PCR with the primer ( $5^{\prime}$-AATTGGATCCATGGCGCAAAGGTACGACGA$\left.3^{\prime}\right)$ and $\left(5^{\prime}\right.$-AATTGGATCCTTATGTGCTGGGGGAAGCTA- $\left.3^{\prime}\right)$ or $\left(5^{\prime}\right.$ AATTGGATCCATGACAGGTGACGATGATGAC-3')and(5'-AATTGG ATCCTTACATGTAGTGCCACTGCC- $3^{\prime}$ ). These fragments were inserted into pEF-BOS-GST vector. The expression vector for H2B-GFP was described previously (Kanda et al., 1998). The pGL3-SV40 vector was from Promega, the pCAG-GFP vector from Addgene, and the pRL-TK vector from Promega. The cDNAs of Pax6 (GenBank accession number AJ292077.1) and Smad1 (GenBank accession number AH010073.2) were inserted into $\mathrm{PCAG}$ vectors.

To construct shRNA-expressing vectors, oligonucleotides targeting the region in the Meis1 coding sequence Meis1shRNA-1 (5'-GCACAAG ATACAGGACTTACC-3'), Meis 1shRNA-2 (5' -GGTGTTCGCCAAACA GATTCG-3'), Meis1shRNA-3 (5'-TAAATTGTCACATAATTCC-3') or a control scrambled sequence (Kawauchi et al., 2006) and their complementary sequences were inserted into the mU6pro vector (Yu et al., 2002). All contained a nine-base hairpin loop sequence ( $5^{\prime}$-TTCAAG AGA- $\left.3^{\prime}\right)$. The DNA fragment containing the Pax6 enhancer was generated by PCR with the primers $5^{\prime}$-GAGTTGCAAGGTATTCAACT- $3^{\prime}$ and 5'-TAAGCCCCTACCTTCCAGTC-3' (Pax6 Up-Luc) or 5'-GACAAA TGTCCATCCTGTAG-3' and 5' -TAAGCCCCTACCTTCCAGTC-3' ( $\triangle$ EnPax6Up-Luc). These fragments were inserted into pGL3-SV40 vector.

Antibodies. Anti-bromodeoxyuridine (BrdU) (1:200; sheep; Abcam; RRID:AB_302944), cleaved Caspase-3 (1:100; rabbit; Cell Signaling Technology; RRID:AB_2687881), parvalbumin (1:200; mouse; SigmaAldrich; RRID:AB_477329), Tbr2 (1:200; rat; eBioscience), L1 (1:500; rat; Millipore; RRID:AB_2133200), phospo-histone H3 (1:200; rabbit; Cell Signaling Technology; RRID:AB_331535), Phospho-Smad1/5/8 (1: 200; rabbit; Cell Signaling Technology; RRID:AB_331671), Smad1 (1: 500; rabbit; Cell Signaling Technology; RRID:AB_2107780), Smad5 (1:500; rabbit; Cell Signaling Technology; RRID:AB_2193632), Pax6 (1:500; rabbit; Covance), Pax6 (1:200; goat; Santa Cruz Biotechnology; RRID: AB_2236691), GFP (1:50; rat; a kind gift from Dr. A. Imura, Foundation 
for Biomedical Research and Innovation, Kobe, Japan), Ki67 (1:500;rat; eBioscience), GFAP (1:1; rabbit; Dakocytomation), GFAP (1:200 rat; Thermo Fisher Scientific), BLBP (1:200 goat; R\&D Systems), Calbindin (1:500; rabbit; Millipore Bioscience Research Reagents; RRID:AB_2068336), Calbindin (1:200 mouse; Abcam; RRID:AB_2040664), NeuN (1:200; mouse; Millipore; RRID:AB_177621), Sox9 (1:500; goat; R\&D Systems; RRID:AB_2194160), and Atoh1 (1:1000, rabbit) (Yamada et al., 2014) were purchased or obtained as gifts. Anti-Meis1 antibody was generated as follows. The fragment of mouse Meis1 full-length (Full: 1-390 aa) or N-terminal side of homeobox domain (NT: 191-213 aa) was inserted into pMAL-c2 (New England Laboratories) or pGEX-4T-2 (GE Healthcare), respectively. Maltose-binding protein (MBP) and glutathione $S$-transferase (GST) fusion proteins were expressed in Escherichia coli BL21 (DE3) and purified according to the instructions of the manufacturer. Polyclonal rabbit anti-Meis1 antibody was prepared against MBP-Meis1-Full as an antigen and then purified by use of GST-Meis1-NT.

Immunohistochemistry. Tissues were fixed with $4 \%$ paraformaldehyde (PFA) in PBS and cryoprotected with $30 \%$ sucrose in PBS. After tissues were embedded in optimal cutting temperature (OCT) compound, cryosections were made at $14 \mu \mathrm{m}$. Sections were incubated in blocking buffer containing $1 \%$ BSA and $0.1 \%$ Triton X-100 in PBS at room temperature (RT) for $1 \mathrm{~h}$ and subsequently immunolabeled using the following primary antibodies in blocking buffer at $4^{\circ} \mathrm{C}$ overnight. Specimens were subsequently rinsed with PBS and incubated with secondary antibodies conjugated with Alexa Fluor 488, Alexa Fluor 568, Alexa Fluor 594, or Alexa Fluor 647 (1:400; Invitrogen) and DAPI (1:5000; Invitrogen) in blocking buffer containing $1 \%$ BSA and $0.2 \%$ Triton X-100 in PBS at RT for $2 \mathrm{~h}$. Fluorescence images were acquired using a Zeiss LSM 780 confocal microscope system (Carl Zeiss) and ZEN 2009 software. Quantification of the fluorescence intensity of immunolabeled cells was performed using the "Measure" and "Plot Profile" functions of ImageJ.

Cell cycle exit assay. Mice were given an intraperitoneal injection of $\mathrm{BrdU}$ at $100 \mathrm{mg} / \mathrm{kg} ; 24 \mathrm{~h}$ later, tissues were fixed and subjected to immunohistochemical analyses as follows. After incubation with the anti-Ki67 antibody, tissue sections were postfixed with 4\% PFA at RT for $20 \mathrm{~min}$ and treated with $2 \mathrm{~N}$ hydrochloric acid at $37^{\circ} \mathrm{C}$ for $30 \mathrm{~min}$. Sections were rinsed in PBS, incubated with anti-BrdU antibody overnight, and then incubated with secondary antibodies to visualize BrdU and Ki67 signals.

It is known that the cell cycle length is $\sim 16-18 \mathrm{~h}$ in GCPs (Contestabile et al., 2009). When BrdU is administered to the animals, it is transiently incorporated in cells at S-phase. The BrdU-incorporated cells should undergo cell division once (but never twice) by $24 \mathrm{~h}$ after BrdU administration. Therefore, at the $24 \mathrm{~h}$ time point after BrdU administration, Ki67-negative, BrdU-positive cells should represent cells that have exited from the cell cycle within the last $24 \mathrm{~h}$. Therefore, the ratio of Ki67-negative, BrdU-positive cells/BrdU-positive cells can be used to determine the "cell cycle exit ratio" during the last $24 \mathrm{~h}$.

In vivo electroporation. Pregnant ICR mice were purchased from SLC Japan. Postnatal mice were anesthetized by placing on ice for $1 \mathrm{~min}$, after which they were put on a heated plate (37 degrees). A small incision was made on the skull leaving the pial surface intact at P1, P5, or P8. Three microliters of plasmid DNA $(3 \mu \mathrm{g} / \mu \mathrm{l})$ in $\mathrm{H}_{2} \mathrm{O}$ containing Fast Green was injected on the pial surface. Holding the brain with forceps-type electrode (Nepa Gene), $50 \mathrm{~ms}$ of $70 \mathrm{~V}$ electric pulses was delivered eight times at intervals of $150 \mathrm{~ms}$ with a square electroporator (Nepa Gene). After electroporation, the wound was carefully wiped and the mouse allowed to spontaneously recover. After harvest, electroporated brains were cut into $14 \mu \mathrm{m}$ sagittal sections with a cryostat. Fluorescence images of frozen sections of GFP-expressing mouse brains were captured by LSM780 (Zeiss) laser scanning confocal microscopes. Cells in the lobules IV-VII were found to be the most frequently transfected. Experienced experimenters are able to target similar sites along the anteropositerior axis for electroporation. Mediolateral sites of transfection can be controlled by orientation of electrodes against the cerebellum. Coelectroporation with EGFP- and mCherry-expressing vectors indicated that the coelectroporation efficiency was $91.1 \pm 3.9 \%$. At least three or four mice were analyzed for each electroporation experiment. For quantification, at least five sections per mouse were analyzed.
Luciferase assay. Neuro2a cells were grown in DMEM containing 10\% FBS. Cells were transfected using Trans Fectin reagent (Bio-Rad). Cells in 24-well plates were cotransfected with expression plasmids for Meis1 and reporter plasmids, together with Renilla luciferase vector (Promega). Forty-eight hours after transfection, cells were lysed with Reporter Lysis Buffer (Promega). The Dual-Glo Luciferase Assay System (Promega) was used to determine firefly and Renilla luciferase activities according to the manufacturer's instructions. Measurements were performed with a multilabel counter (Wallac 1420) and firefly luciferase values were normalized to Renilla luciferase values.

Cerebellar slice culture. WT P8 cerebella were embedded in UltraPure LMP Agarose (Invitrogen) and $300 \mu \mathrm{m}$ sagittal slices were obtained with a vibratome. P8 cerebellar slices were placed on a Millicell-CM (Millipore), mounted in collagen gel, and soaked in culture medium (DMEM supplemented with 5\% horse serum (Invitrogen), 5\% FBS (Invitrogen), 10 ng/ml EGF (PeproTech), 10 ng/ml bFGF (PeproTech), 1× B27 (Invitrogen), $1 \times \mathrm{N} 2$ (LifeTechnology), $3 \mathrm{~mm}$ L-glutamine. The slices in Millicel-CM dishes were kept at $37^{\circ} \mathrm{C}$ in an incubator. After $48 \mathrm{~h}$, cerebellar slices were fixed with $4 \%$ PFA in PBS. Fixed slices were then blocked with $1 \%$ BSA, $0.02 \%$ Triton/PBS at RT for 30 min, incubated in the same solution containing a primary antibody at $4^{\circ} \mathrm{C}$ overnight, washed with PBS at RT for 5 min 3 times, and incubated with fluorescenceconjugated secondary antibody-containing solution (1\% BSA, $0.02 \%$ Triton/PBS) at RT for $2 \mathrm{~h}$. After slices were embedded in OCT compound, cryosections were made at $14 \mu \mathrm{m}$. At least three or four mice and five slices per mouse were analyzed in each experiment.

Cell culture and transfection. Neuro2a cells were maintained in DMEM containing $10 \%$ fetal calf serum and transfected with expression plasmids using Trans Fectin reagent (Bio-Rad) according to manufacturer's instructions. Transfected cells were harvested after $48 \mathrm{~h}$ in the following buffer: $50 \mathrm{~mm}$ Tris, pH 8.1, $200 \mathrm{~mm} \mathrm{NaCl}, 0.1 \%$ Triton X-100, $12.5 \mathrm{~mm}$ EDTA, with protease inhibitor mixture (Roche).

GC cultures and transfection. Cerebella from postnatal day 6 (P6) mice were dissected and incubated at $37^{\circ} \mathrm{C}$ for $30 \mathrm{~min}$ in papain solution $(125$ $\mu \mathrm{g}$ of papain, $0.25 \%$ trypsin-EDTA in Hank's balanced salt solution; Sigma-Aldrich) for $15 \mathrm{~min}$ at $37^{\circ} \mathrm{C}$. To collect a fraction enriched in GCPs, the cell suspension was loaded onto a step gradient of 35\%-60\% Percoll (Sigma-Aldrich) and centrifuged at $2000 \mathrm{rpm}$ for $20 \mathrm{~min}$ at room temperature. GCPs were harvested from $60 \%$ and $35 \%$ Percoll step interface and added to ice-cold PBS. Cells were centrifuged at $1000 \mathrm{rpm}$ for $5 \mathrm{~min}$. GCPs were plated on cover glasses coated with $1 \mathrm{mg} / \mathrm{ml}$ poly-Llysine (Sigma-Aldrich) and maintained in DMEM supplemented with $5 \%$ horse serum (Invitrogen), 5\% FBS (Invitrogen), $10 \mathrm{ng} / \mathrm{ml} \mathrm{EGF} \mathrm{(Pe-}$ proTech), $10 \mathrm{ng} / \mathrm{ml}$ bFGF (PeproTech), $1 \times \mathrm{B} 27$ (Invitrogen), $1 \times \mathrm{N} 2$ (Life Technology), 3 mM L-glutamine, and $1 \mu \mathrm{M}$ SAG (SAG dyhydrochloride; Sigma-Aldrich). GCPs were transfected with Neon Transfection systems (Thermo Fisher Scientific) according to the manufacturer's instruction (pulse voltage: 1200 , pulse width: 30 , pulse no: 1 ) and harvested after $24 \mathrm{~h}$ in the following buffer: $50 \mathrm{~mm}$ Tris, $\mathrm{pH} 8.1,200 \mathrm{~mm} \mathrm{NaCl}, 0.1 \%$ Triton X-100, 12.5 mm EDTA, with protease inhibitor mixture (Roche).

ChIP assay. Harvested GCPs were cross-linked by $1 \%$ formaldehyde at room temperature for $15 \mathrm{~min}$ and washed with $0.125 \mathrm{~m}$ glycine. Fixed tissue was rinsed twice with PBS and resuspended in lysis buffer (1\% SDS, 10 mм EDTA, 50 mм Tris-HCl, pH 8.1, and Complete, Mini, EDTA-free; Roche). Lysate was sonicated $5 \mathrm{~min}$ (30 s on/30 s off) using UR-20P (TOMY) and centrifuged. The supernatant was used immediately in ChIP experiments. Then, $50-150 \mu \mathrm{g}$ of sonicated chromatin was diluted by 10 in ChIP dilution buffer (16.7 mm Tris- $\mathrm{HCl}, \mathrm{pH} 8.1,167 \mathrm{~mm} \mathrm{NaCl}, 1.1 \%$ Triton X-100, $1.2 \mathrm{~mm}$ EDTA, 0.01\% SDS) and precleared for $30 \mathrm{~min}$, rotating at $4^{\circ} \mathrm{C}$, with $75 \mu \mathrm{l}$ of blocked beads (Protein A Sepharose; GE Healthcare) before overnight incubation with 2-4 $\mu \mathrm{g}$ of the Meis1 antibody. The beads were washed for 5 min once in low-salt buffer $(0.1 \%$ SDS, 1\% Triton X-100, 2 mм EDTA, 20 mm Tris-HCl, pH 8.1, 150 mм $\mathrm{NaCl})$, once in high-salt buffer $(0.1 \%$ SDS, $1 \%$ Triton X-100, $2 \mathrm{~mm}$ EDTA, $20 \mathrm{~mm}$ Tris- $\mathrm{HCl}, \mathrm{pH} 8.1,500 \mathrm{~mm} \mathrm{NaCl}$ ), and twice in TE wash buffer (10 mm Tris-HCl, 1 mm EDTA). ChIPed material was eluted after $15 \mathrm{~min}$ incubations at room temperature with $250 \mu \mathrm{l}$ of elution buffer ( $1 \% \mathrm{SDS}, 0.1 \mathrm{M} \mathrm{NaHCO}_{3}$ ). Chromatin was reverse-crosslinked by adding $20 \mu \mathrm{l}$ of $5 \mathrm{M} \mathrm{NaCl}$ and incubated at $65^{\circ} \mathrm{C}$ for $4 \mathrm{~h}$ and DNA was treated with 

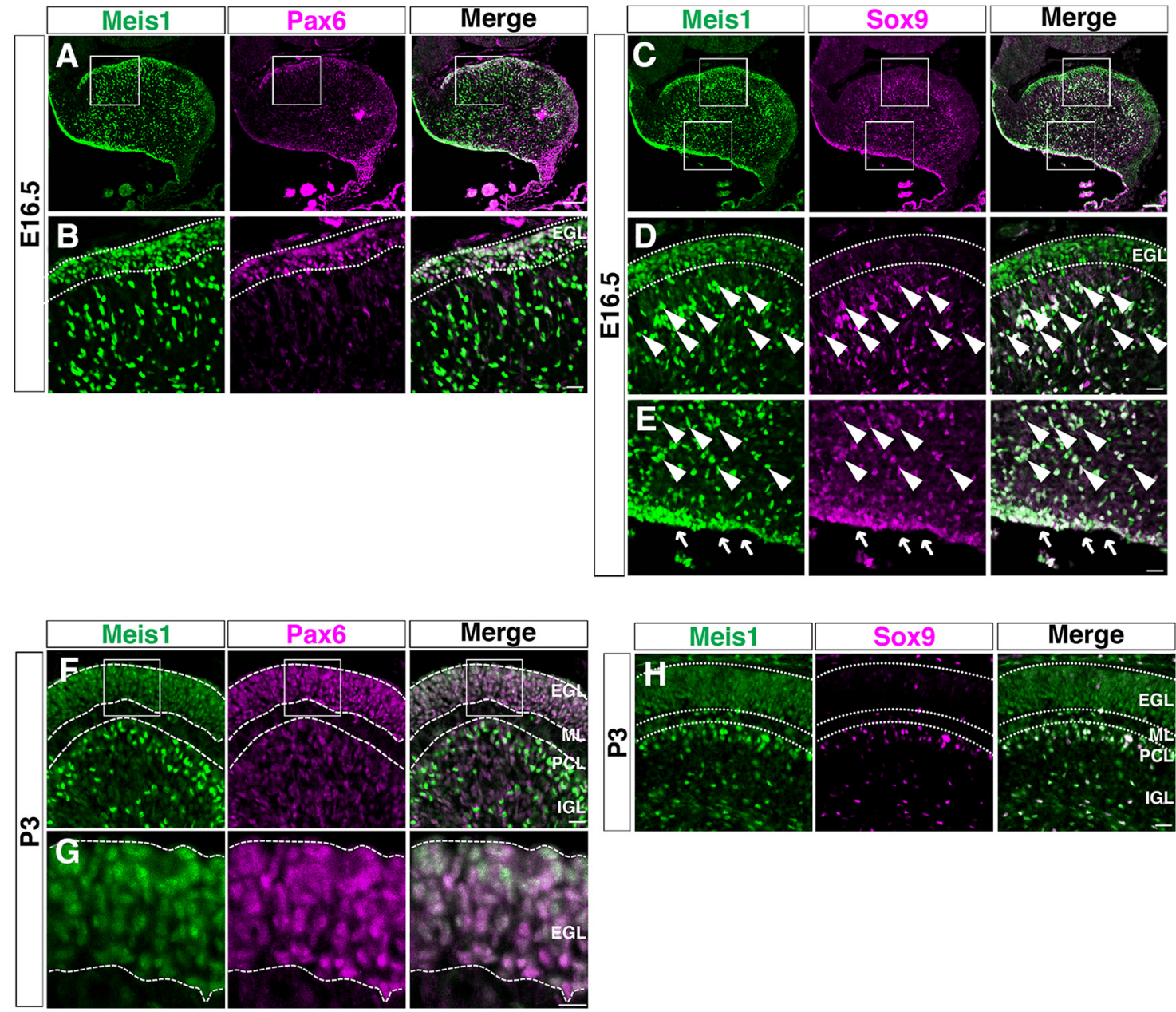

Figure 1. Distribution of Meis1 protein in the cerebellum during development. $\boldsymbol{A}-\boldsymbol{H}$, Coimmunostaining with Meis1 and indicated markers in E16.5 $(\boldsymbol{A}-\boldsymbol{E})$ and P3 $(\boldsymbol{F}-\boldsymbol{H})$ cerebellar sagittal sections. $\boldsymbol{B}, \boldsymbol{G}$, High-magnification images of the boxed regions in $\boldsymbol{A}$ and $\boldsymbol{F}$, respectively. $\boldsymbol{D}, \boldsymbol{E}$, High-magnification images of the upper and lower boxed regions in $\boldsymbol{C}$, respectively. Scale bars: $\boldsymbol{A}, \boldsymbol{C}, 100$ $\mu \mathrm{m} ; \boldsymbol{B}, \mathbf{D}-\boldsymbol{F}, \boldsymbol{H}, 20 \mu \mathrm{m} ; \boldsymbol{G}, 10 \mu \mathrm{m}$.

RNase and proteinase $\mathrm{K}$ and extracted by phenol-chloroform. DNA was resuspended in $25 \mu \mathrm{l}$ of TE ( $10 \mathrm{~mm}$ Tris- $\mathrm{HCl}, \mathrm{pH} 8.1,1 \mathrm{~mm}$ EDTA $)$ and $2 \mu \mathrm{l}$ was used as template for PCRs using primer pairs to amplify the Meis1 binding consensus (MBC) region of the Pax6 gene.

Statistical analyses. Pairwise comparisons between the means of different groups were performed using a Student's $t$ test (two tailed, unpaired). The difference between two subsets of data was considered statistically significant if the Student's $t$ test gave a significance level of $p<0.05, p<$ 0.01 , or $p<0.001$. One, two, or three asterisks in each graph indicate that the $p$-value is $<0.05,<0.01$, or $<0.001$, respectively. The data are reported as the mean \pm SEM.

\section{Results}

Expression profile of Meis1 in the cerebellum during development

To investigate the expression of Meis1, we generated an antiMeis1 antibody. Our immunohistochemical studies revealed that Meis1 protein is localized in several regions of the cerebellar primordium (Fig. 1A-E). In embryonic day (E) 16.5 cerebella, Meis 1 was detected in Pax6-positive cells in the EGL, suggesting that this protein is expressed in GCPs (Fig. $1 A, B$ ). In addition, Meis1 is also expressed in Sox9-positive cells (Fig. $1 C-E$ ). One population of Sox9-positive cells is cerebellar neuroepithelial cells (arrows in Fig. $1 E$ ) and another population might be cerebellar pluripotent precursor cells (arrowheads in Fig. 1D,E; Stolt et al., 2003; Vong et al., 2015), which are not well characterized. At P3, Meis1 ex- pression was still observed in cells of GC lineage (GCPs in the EGL and GCs in the ML/IGL; Fig. 1F, G) and Sox9-positive cells inside the cerebellum (Fig. $1 H$ ).

In the P10 cerebella, coimmunostaining with Pax6 showed that all Pax6-positive cells expressed Meis1, suggesting that Meis1 was expressed in GCPs in the EGL, migrating GCs in the ML and differentiating GCs in the IGL (Fig. 2A,B). Conversely, Meis1 was also expressed in non-GC-lineage cells (Pax6-negative cells, arrowheads in Fig 2B). Measurement of fluorescence intensities per unit area suggested stronger expression of Meis1 in non-GC lineage cells than in GC-lineage cells (Fig. 2C). Coimmunostaining with Tbr2, a marker for unipolar brush cells (UBCs), and calbindin, a marker for Purkinje cells, revealed that Meis1 was not expressed in UBCs or Purkinje cells (Fig. 2D-F). The strong Meis1-positive cells adjacent to Purkinje cells in the Purkinje cell layer (PCL) are likely Bergmann glia (arrowheads in Fig. 2F). Similar to the P3 cerebella, all Sox9-positive cells expressed Meis1 in the P10 cerebella (Fig. $3 A, B$ ). The Meis1 expression in Sox9positive cells (arrowheads in Fig. $3 A, B$ ) was stronger than that in GCs (arrows in Fig. $3 B$ ), as is shown in the quantitative analyses of the fluorescence intensities per unit area (Fig. $3 C$ ). We confirmed that Pax6-expressing and Sox9-expressing cells never overlap in the cerebellum at this stage (Fig. $3 D, E$ ). Because these cells also expressed GFAP and BLBP (arrowheads in Fig. $3 F, G$ ), this popula- 

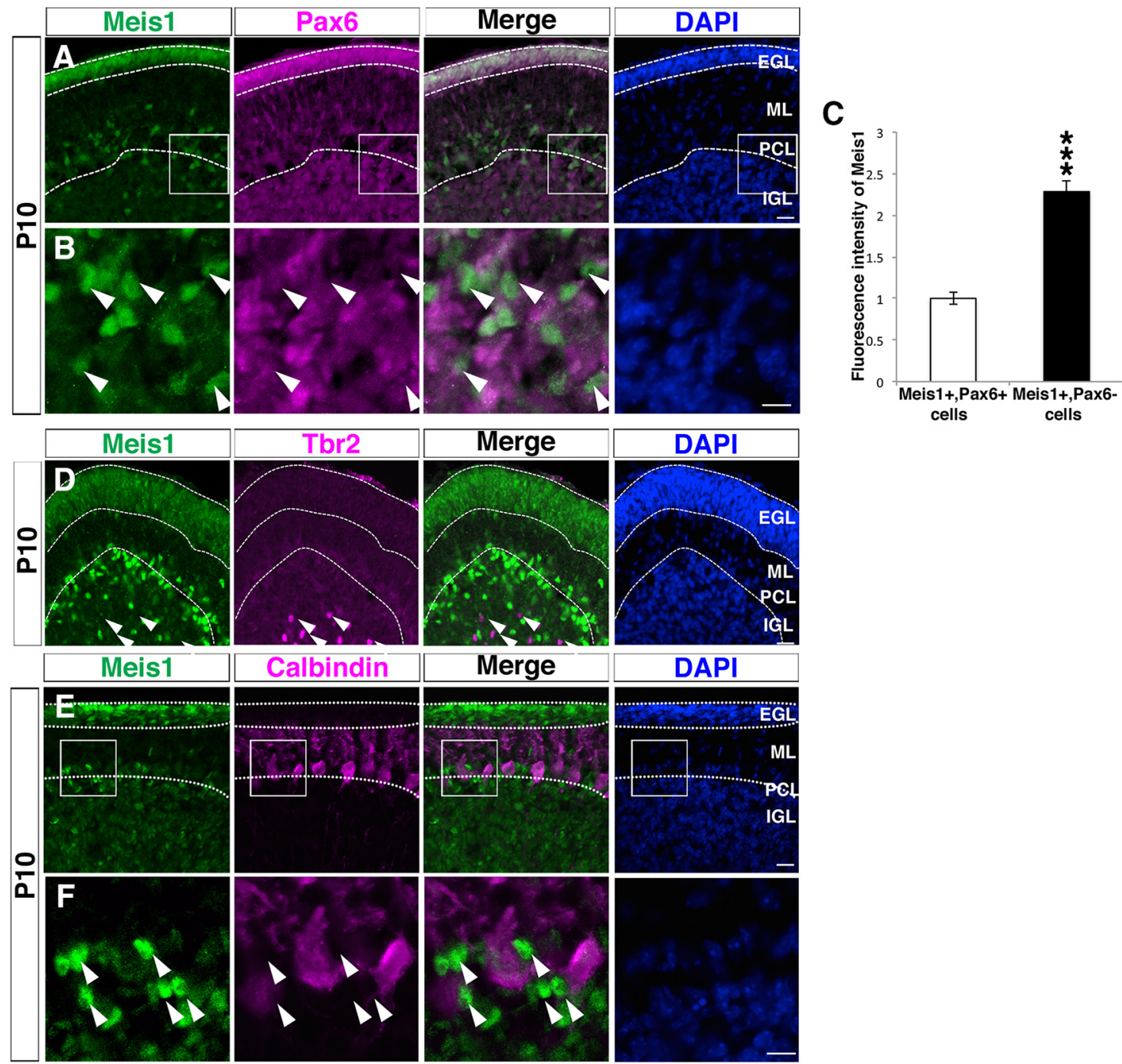

Figure 2. Distribution of Meis 1 protein in the postnatal cerebellum. $A$, Double immunostaining with Meis 1 and pax 6 in P10 cerebellar sagittal sections. $\boldsymbol{B}$, High-magnification images of the boxed regions in $\boldsymbol{A}$. C, Relative fluorescence intensities of Meis1 per unit area in Meis1-positive/Pax6-positive cells and Meis1-positive/Pax6-negative cells. $n=4$ mice, 60 cells. D, Double immunostaining with Meis1 and Tbr2 in P10 cerebellar sagittal sections. Arrowheads indicate Tbr-2 positive UBCs. $\boldsymbol{E}$, Double immunostaining with Meis1 and calbindin in P10 cerebellar sagittal sections. $\boldsymbol{F}$, High-magnification images of the boxed regions in $\boldsymbol{E}$. Scale bars: $\boldsymbol{A}, \boldsymbol{D}, \boldsymbol{E}, 20 \mu \mathrm{m} ; \boldsymbol{B}, \boldsymbol{F}, 10 \mu \mathrm{m}$. Data are shown as mean \pm SEM. ${ }^{* * *} p<0.001$, Student's $t$ test.

tion seemed to include Bergmann glia, astrocytes, and pluripotent precursor cells (Pompolo and Harley, 2001; Stolt et al., 2003; Fleming et al., 2013; Parmigiani et al., 2015; Vong et al., 2015).

At P21, Meis1 expression was not observed in any regions in the cerebellum (Fig. 3H). These results indicate that Meis1 is expressed in cells in the GC lineage and Sox9-positive cells in the cerebellum during development, but its expression is lost after most cerebellar neurons attain their appropriate positions, thus implying that Meis 1 is involved in the development of those cells. Here, however, we will focus on the function of Meis1 in the GC lineage.

\section{Knock-down of Meis1 causes abnormal GC development}

To analyze the physiological function of Meis1, we generated three knock-down vectors (sh-Meis1-1, sh-Meis1-2, and sh-Meis1-3) that efficiently suppress Meis1 expression in vitro (Fig. $4 A, B$ ). We then injected the knock-down vector into the submeningeal space just above the EGL at specific developmental stages, followed immediately by electroporation. Animals were killed several days after electroporation and electroporated cells were visualized by coelectroporated H2B-GFP (Kanda et al., 1998) or GFP, which label the nuclei or entire cell bodies, respectively. This electroporation strategy enabled us to specifically and efficiently introduce the vectors into GCPs in the EGL, avoiding other cell types such as the Sox9-positive cells, GABAergic interneurons (Pax2-positive cells), or Purkinje cells (Fig. 4C-E). We observed that all sh-Meis1 vectors efficiently suppressed Meis1 expression in electroporated cells (Fig. $4 F$ ), leading to similar results in all knock-down experiments in this study. The coelectroporation efficiency of two vectors is $>90 \%$ ( $91.1 \pm 3.9 \%$, see Materials and Methods, "In vivo electroporation" section).

We first performed electroporation at P1 and examined cerebella $3 \mathrm{~d}$ after electroporation (at P4). Under these experimental conditions, the majority of introduced cells were found in the EGL, whereas some were detected in the ML and the IGL (Fig. $4 D-H)$. Interestingly, sh-Meis1-electroporated cells were rarely immunoreactive to Pax6 (arrowheads in Fig. 4H), whereas adjacent nonelectroporated cells and control-electroporated cells strongly expressed Pax6 (Fig. 4G,H), a difference that was statistically confirmed (Fig. 4I). Moreover, cointroduction of the knock-down-resistant Meis1 with sh-Meis1 rescued the expression of Pax6 (Fig. $4 J, K$ ). Pax6 expression was even more strongly induced in the knock-down-resistant Meis1-introduced cells 


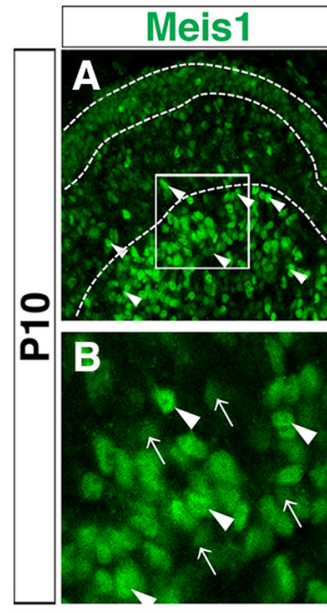

Pax6

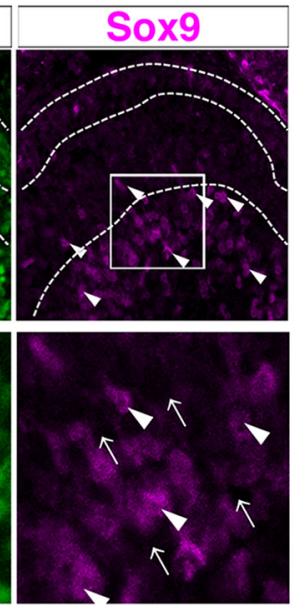

Sox 9
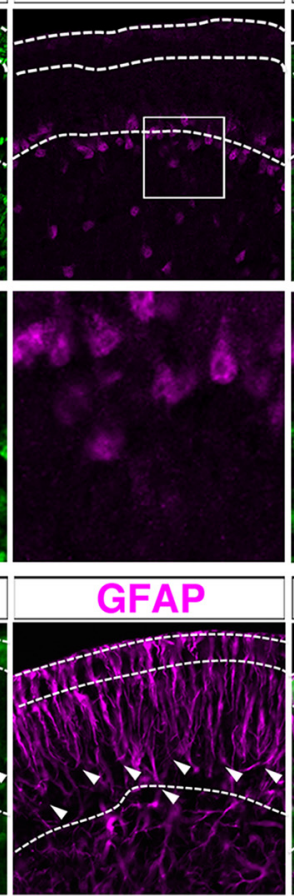

BLBP



DAPI

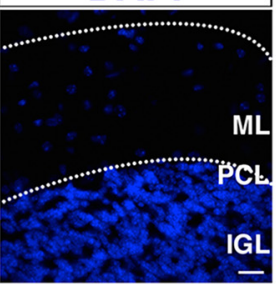

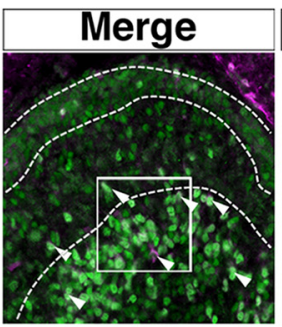



DAPI
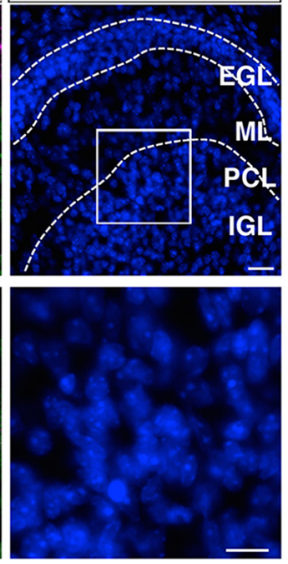

DAPI
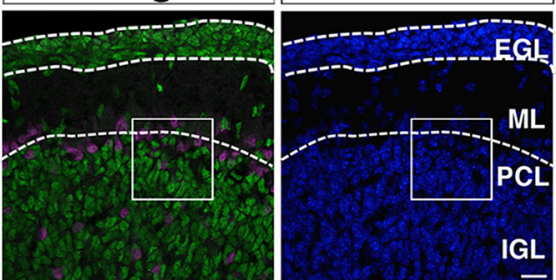

IGL
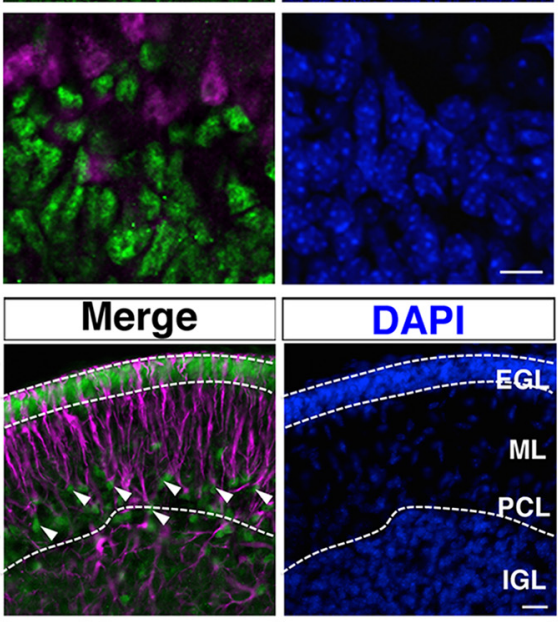

IGL

\section{DAPI}


IGL.

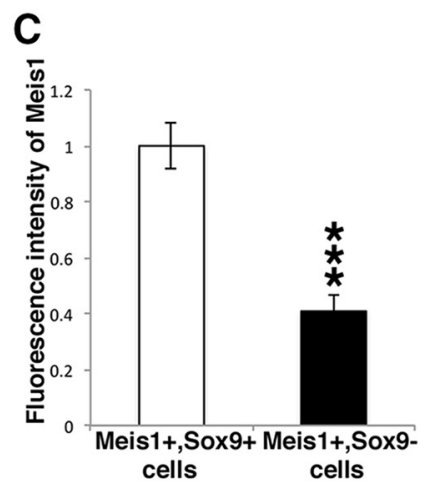

Figure 3. Expression of Meis 1 protein in astrocyte lineage. A. Double immunostaining with Meis 1 and Sox 9 in P10 cerebellar sagittal sections. $\boldsymbol{B}$, High-magnification images of the boxed regions in $\boldsymbol{A}$. C, Relative fluorescence intensities of Meis1 per unit area in indicated cells. $n=4$ mice, 60 cells. D, Double immunostaining with Pax6 and Sox9 in P10 cerebellar sagittal sections. $\boldsymbol{E}$, High-magnification images of the boxed regions in $\boldsymbol{D}$. $\boldsymbol{F}, \boldsymbol{G}$, Double immunostaining with Meis1 and GFAP or BLBP in P10 cerebellar sagittal sections. $\boldsymbol{H}$, Immunostaining with Meis1 in P21 cerebellar sagittal sections. Scale bars: $\boldsymbol{A}, \boldsymbol{D}, \boldsymbol{F}, \boldsymbol{G}, \boldsymbol{H}, 20 \mu \mathrm{m} ; \boldsymbol{B}, \boldsymbol{E}, 10 \mu \mathrm{m}$. Data are shown as mean \pm SEM. ${ }^{* * *} p<0.001$, Student's $t$ test. 

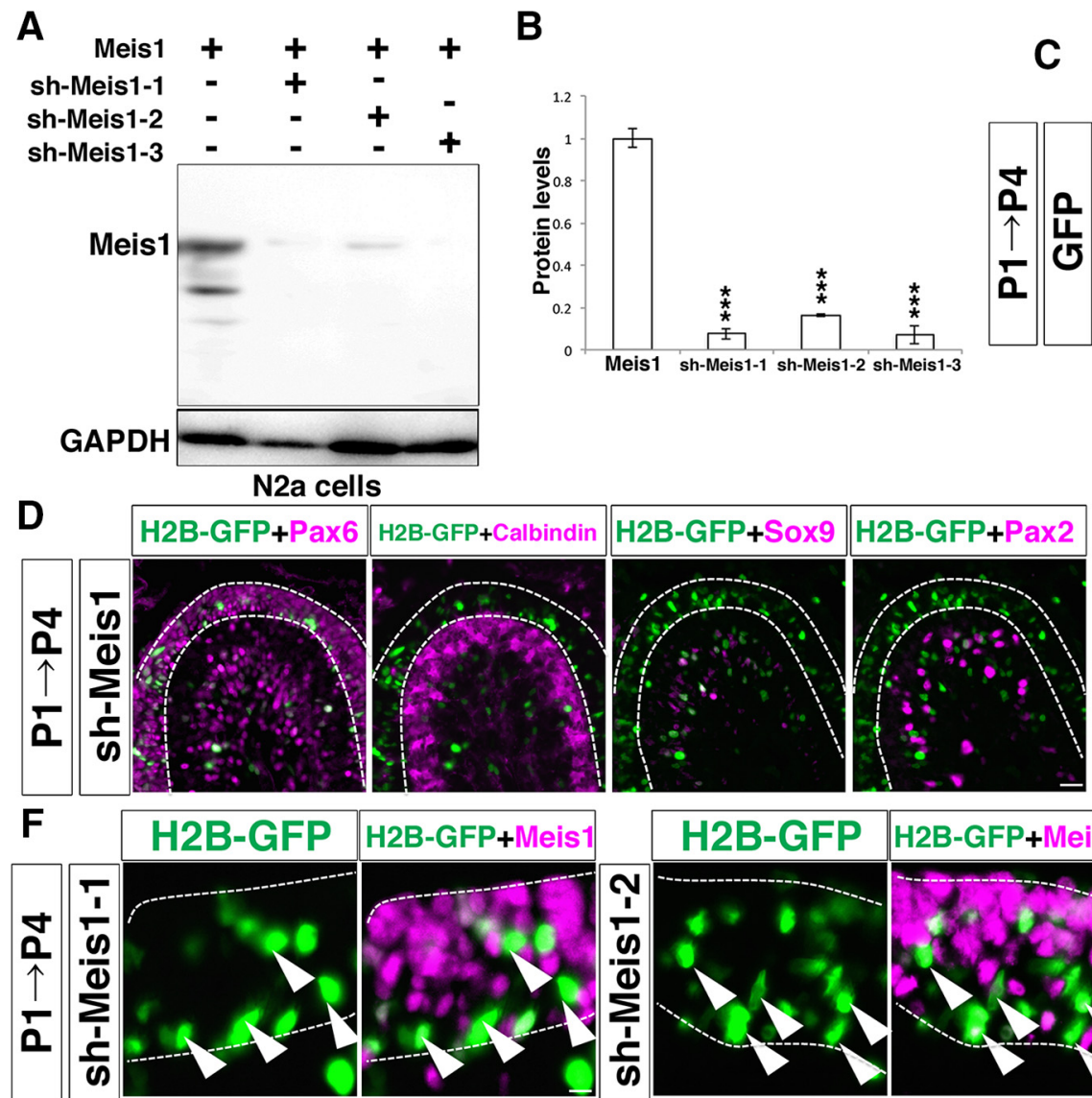

E
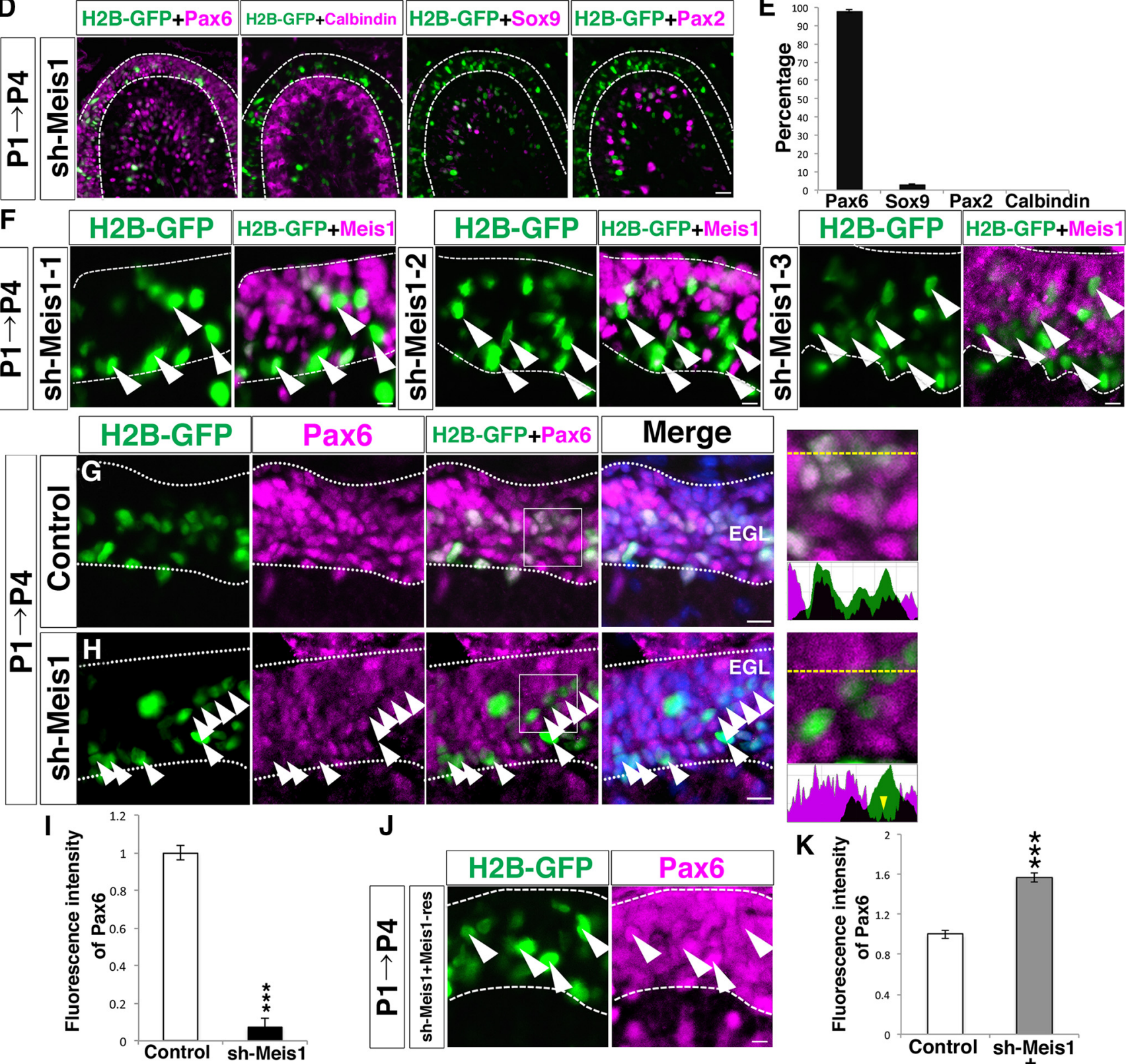
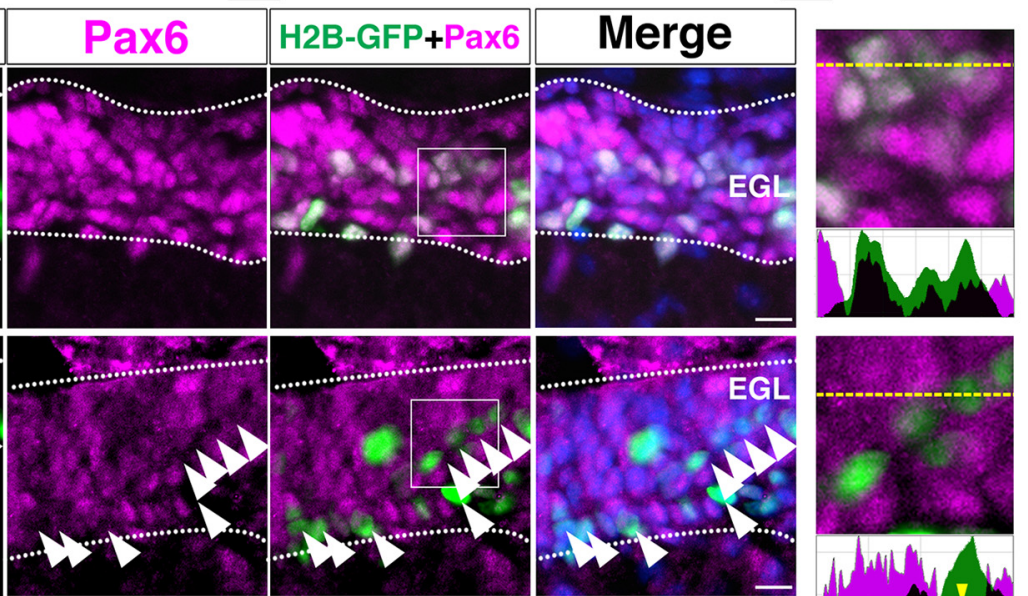

$\mathbf{J}$



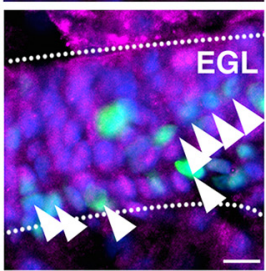
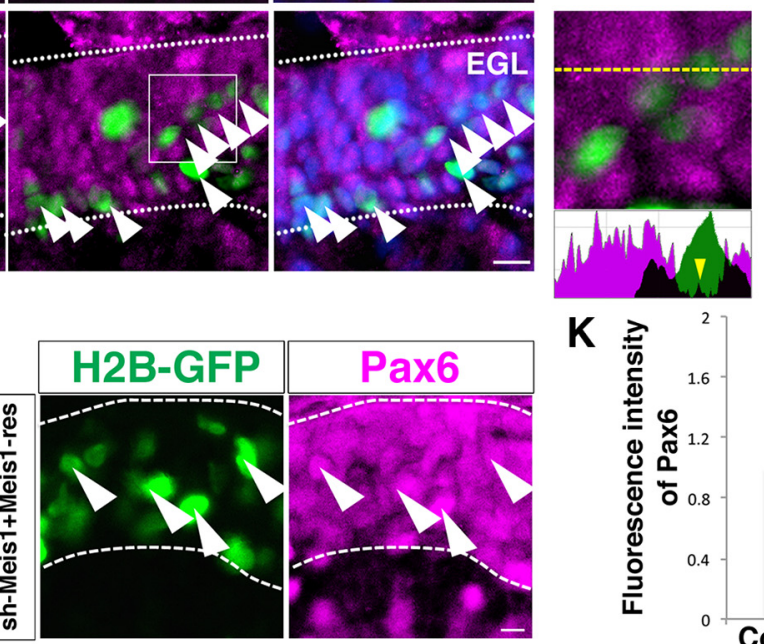

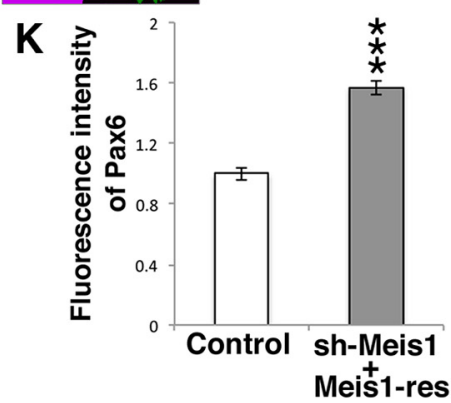

Figure 4. Effect of Meis 1 knock-down in GCPs/GCS. A, Western blot analysis with indicated antibodies on extracts from N2a cells transfected with a Meis1 expression vector with or without the Meis1 knock-down vector (sh-Meis1-1, sh-Meis1-2, and sh-Meis1-3). B, Quantification of Meis1 protein in A. C, Left, Representative image of P4 brain that was electroporated with GFP at P1. Right dorsal view, Sagittal section of the cerebellum stained with GFP and DAPI. D, Coimmunostaining with GFP and indicated antibodies to P4 cerebella that were electroporated with H2B-GFP at P1. $\boldsymbol{E}$, Percentages of immunoreactivity to indicated antibodies in H2B-GFP-positive cells. Pax6: $97.9 \pm 1.56 \%$, Sox9: $3.04 \pm 0.78 \%$, Pax2:0\%, Calbindin: $0 \%, n=4$ mice, 16 slices. $\boldsymbol{F}$, Immunostaining with Meis1 and GFP to P4 cerebella that were electroporated with sh-Meis1-1 (or sh-Meis1-2 or sh-Meis1-3) and H2B-GFP at P1. Arrowheads indicate sh-Meis1-introduced cells in which Meis1 expression was suppressed. $\mathbf{G}, \boldsymbol{H}$, Left, Immunostaining with Pax6 and GFP in P4 cerebella that were electroporated with control shRNA and sh-Meis1 at P1. (Figure legend continues.) 
compared with control (Fig. $4 K$ ). We think that this may have been caused by the strong exogenous expression of Meis1. These findings suggest that Meis1 is required for the expression of Pax6 in GCPs and GCs in the developing cerebellum. Despite the loss of Pax6 expression, the electroporated cells retained their GC identity (described below).

The morphology of sh-Meis1-electroporated cells appeared somewhat disorganized (Fig. 5A-D). They possessed much wider processes, which were wavy, resembling lamellipodia-like structures (Fig. $5 B, D$ ). Accordingly, the cell area visualized with GFP per cell was much larger in the sh-Meis1-electroporated cerebella than control (Fig. 5G). This abnormal morphology was rescued by coelectroporation with the knock-down-resistant Meis 1 (Fig. $5 \mathrm{H}, \mathrm{I}$ ). It was reported previously that processes extending from explant cultures of Pax6 knock-out cerebellum exhibited a lamellipodia-like structure (Yamasaki et al., 2001). Similarly, electroporation with shRNA for Pax6 (sh-Pax6) under the same conditions also resulted in a disorganized cellular GC morphology with lamellipodia-like processes (Fig. $5 E-G$ ). These results suggest that the Meis1-Pax6 pathway may be required for proper process formation of GCs.

Next, we calculated the ratios of electroporated cells localized in the EGL, ML, and IGL in the same experiment (Fig. $5 J$ ). No significant differences were observed in cell distribution, suggesting that knock-down of Meis1 or Pax6 did not affect migration of GCs.

To investigate the function of Meis1 during late differentiation of GCs, sh-Meis1 was electroporated into the EGL at P8 (Fig. $5 K, L)$ and brains were fixed at $\mathrm{P} 21$. We observed disorganized morphologies of parallel fibers in sh-Meis1-electroporated GCs with an abnormal vertical component (arrowheads in Fig. 5L). These abnormal processes never overlapped with GFAP, distinguishing them from the processes of Bergmann glia or astrocytes. Similar abnormal morphologies were also observed in sh-Pax6introduced GCs (arrowheads in Fig. 5M), suggesting that the Meis1-Pax6 pathway participates in proper formation of parallel fibers of GCs.

Meis1 regulates Pax6 transcription directly in the cerebellum A transgenic mouse line expressing the lacZ gene under the control of the $5^{\prime}$ upstream sequence of Pax6 (Pax6-lacZ Tg) was generated previously (Williams et al., 1998). In these mice, lacZ expression was strongly observed in the lens and in some parts of the brain, whereas expression of lac $Z$ in the cerebellum was unclear. In the mouse lens, it was shown that Meis1 binds to a short sequence in the Pax6 gene (red box in Fig. 6A,C; MBC region) and directly regulates Pax6 transcription (Zhang et al., 2002). Because our knock-down experiment showed that Meis1 is required for Pax6 expression in GCPs/GCs (Fig. 4G-I), we suspected that, in GCPs/GCs, Meis1 may directly upregulate the

$\leftarrow$

(Figure legend continued.) DAPI signal are shown in merge. Right, High-magnification images of the boxed regions in $\boldsymbol{G}$ and $\boldsymbol{H}$. The GFP (green) and Pax6 (magenta) fluorescence intensities along the yellow dotted lines are plotted in the lower graphs. Merged regions for green and magenta were labeled in black. Yellow arrow indicates that sh-Meis 1 introduced (GFP-positive) cell barely expressed Pax6 (green). I, Relative fluorescence intensities of Pax6 per unit area in GFP-negative and positive cells in the experiment of Figure 4H. $n=4$ mice, 60 cells for each groups. J, Immunostaining with GFP and Pax6 to P4 cerebella that were coelectroporated with sh-Meis1, sh-resistant Meis1 (Meis1-res), and H2B-GFP. Electroporated cells are highlighted by arrows. $\boldsymbol{K}$, Relative fluorescence intensities of Pax6 per unit area in GFP-positive cells of cerebella in $\boldsymbol{G}$ and $\boldsymbol{J} . n=4$ mice, 60 cells for each groups. Scale bars: $\boldsymbol{C}, 200 \mu \mathrm{m} ; \boldsymbol{D}, 20 \mu \mathrm{m} ; \boldsymbol{F}-\boldsymbol{H}, \boldsymbol{J}$, $10 \mu \mathrm{m}$. Data are shown as mean \pm SEM. ${ }^{* * *} p<0.001$, Student's $t$ test. transcription of Pax6, similar to the case in the lens. To test this, we performed luciferase assays in Neuro2a cells (Olmsted et al., 1970). The Meis1 expression vector and a luciferase reporter construct containing the Pax6 upstream sequence (Pax6Up-Luc in Fig. 6A) were cotransfected in Neuro2a cells and luciferase activities were measured (Fig. 6B). We observed a significant increase in luciferase activity when Pax6Up-Luc was introduced with Meis1, but that effect was lost when the MBC region (red box in Fig. $6 A$ ) was deleted from the reporter construct ( $\triangle$ EnPax6UpLuc). This suggests that the MBC region is involved in Meis1induced transcriptional activation of Pax6 in Neuro2a cells.

Next, we tried to purify GCPs from P6 WT cerebellum and found that $>96 \%$ of cells were Pax6/Ki67 double positive, ensuring that most cells in this purification condition were GCPs. To investigate whether Meis1 binds directly to the $\mathrm{MBC}$ region of the Pax6 gene in the cerebellum, we performed a ChIP assay to the purified GCPs. In this experiment, we used the anti-Meis1 antibody to precipitate endogenous Meis 1 protein plus its associating genomic DNA fragments and used PCR primer pairs to amplify the $\mathrm{MBC}$ region (Fig. $6 C-E$ ). Detection of strong signals indicated that Meis1 binds to the MBC region in GCPs in the developing cerebellum to positively regulate $\mathrm{Pax} 6$ transcription.

\section{Deletion of Meis1 in the GC lineage results in disorganized cerebellar structure}

To investigate genetically the role of Meis1 in the cerebellar GCPs/GCs, the Meis1 gene was conditionally ablated using the Cre/LoxP recombination strategy because the whole body loss of Meis1 results in embryonic lethality at E14.5 (Hisa et al., 2004). Mice carrying floxed Meisl alleles (Ariki et al., 2014) were crossed with Atoh1-Cre- $\mathrm{Tg}$ mice (Fujiyama et al., 2009, Yamada et al., 2014) to specifically knock out the Meis1 gene in the GC lineage of their offspring. In P10 cerebella of Meis $1^{\text {flox/flox }} ;$ Atoh1-Cre- Tg (Meis1 homozygous cKO) mice, Meis1 expression was detected only in Sox9-positive cells (Fig. 7A,B), indicating that Meis1 expression was specifically eliminated in the GC lineage. This was also confirmed by the quantification of Meis 1 fluorescent signals as well as immunoblotting of GCP cultures (Fig. $7 C-E$ ).

At $\mathrm{P} 21$, a pronounced reduction in the size of the cerebellum could be seen in Meis 1 cKO homozygotes (Fig. $7 F, G$ ). The morphology of the hemispheres and the vermis was also impaired (Fig. $7 F, G$ ). We performed Nissl staining to further investigate the cerebellar structure of Meis $1 \mathrm{cKO}$ mice during postnatal development. At P10, the cerebellum is much smaller and the structure of the lobules is severely disorganized in the Meis $1 \mathrm{cKO}$ mice (Fig. $7 \mathrm{H}, I$ ). Although relatively fewer cells were observed in the ML of the WT cerebella, numerous cells were found to be abnormally located in the ML of Meis1 cKO homozygotes (Fig. 7J,K). Moreover, we often observed many abnormally clustered cells in the mutant ML (arrowheads in Fig. $7 K$ ).

At P21, disrupted folial formation was observed (Fig. $7 \mathrm{~L}, \mathrm{M}$ ) and the laminar structure (ML-PCL-IGL) was barely recognizable (Fig. $7 \mathrm{~N}, \mathrm{O}$ ) in the cKO homozygotes. The cell bodies of Purkinje cells are not aligned in a monolayer, but rather in multilayers (Fig. $7 \mathrm{~N}, \mathrm{O}$ ). These results suggest that Meis1 expression in the GC lineage is required for proper formation of cerebellar structure.

Immunolabeling with $\mathrm{L} 1$ at $\mathrm{P} 10$ revealed that the orientation of parallel fibers was disrupted in the cKO cerebella (Fig. 8A, B); some fibers curved perpendicularly into the deeper cerebellum (arrow in Fig. 8B). Abnormal clustered cells were always observed at the curving point (dotted line in Fig. 8B). Immunostaining with calbindin showed that cell bodies of Purkinje cells were not 

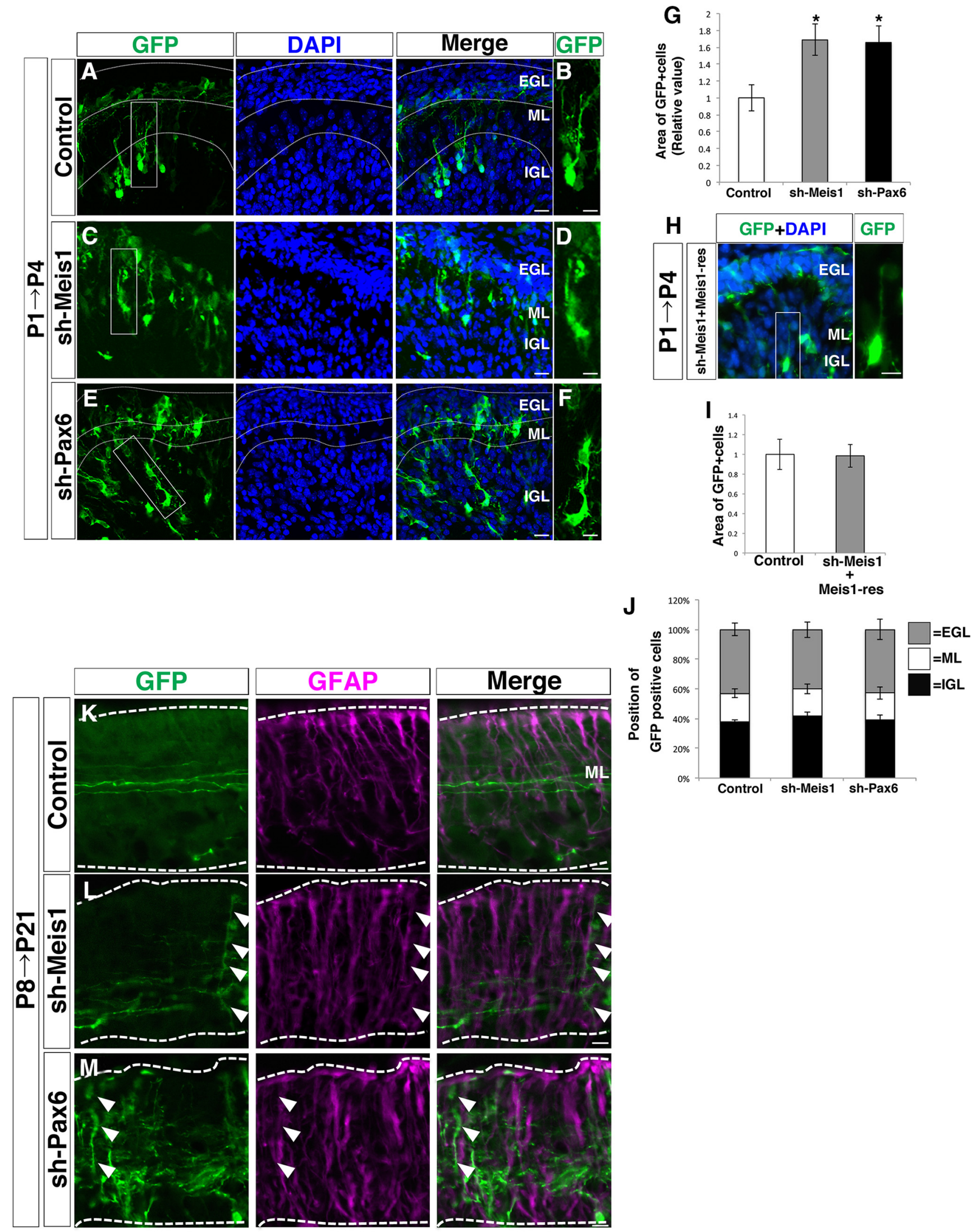

Figure 5. Meis1-Pax6 pathway affects process formation of GCS. $A, C, E$, Immunostaining with GFP in P4 cerebella that were electroporated with indicated shRNA vectors at P1. $\boldsymbol{B}, \boldsymbol{D}, \boldsymbol{F}$, High-magnification of the boxed regions in $\boldsymbol{A}, \boldsymbol{C}$, and $\boldsymbol{E}$. $\boldsymbol{G}$, Relative value of cell area per one cell visualized with GFP. $n=4$ mice, 60 cells for each groups. $\boldsymbol{H}$, Morphology of GCs in the P4 cerebella that were coelectroporated with sh-Meis1, sh-resistantMeis 1 , and GFP. I, Relative value of cell area per one cell visualized with GFP in the experiments of Fig. 4, $A$ and $H . n=4$ mice, 60 cells for each groups. $J$, Positions of GFP-positive cells in $\boldsymbol{A}, \boldsymbol{C}$, and $\boldsymbol{E} . n=4$ mice, 60 cells for each group. $\boldsymbol{K}-\boldsymbol{M}$, Coimmunostaining with GFP and GFAP in P21 cerebella that were electroporated with the indicated shRNA vectors at P8. Scale bars: $\boldsymbol{B}, \boldsymbol{D}, \boldsymbol{F}, \boldsymbol{H}, 10 \mu \mathrm{m} ; \boldsymbol{A}, \boldsymbol{C}, \boldsymbol{E}, \boldsymbol{K}-\boldsymbol{M}, 20 \mu \mathrm{m}$. Data are shown as mean \pm SEM. ${ }^{*} p<0.05$, Student's $t$ test. 
A $4 \mathrm{~kb}$ upstream
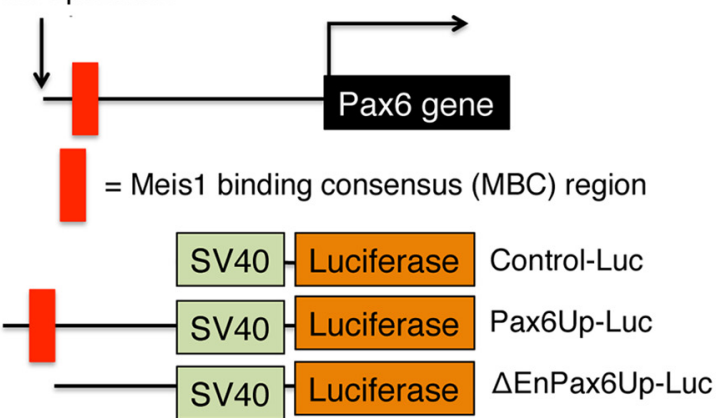

B

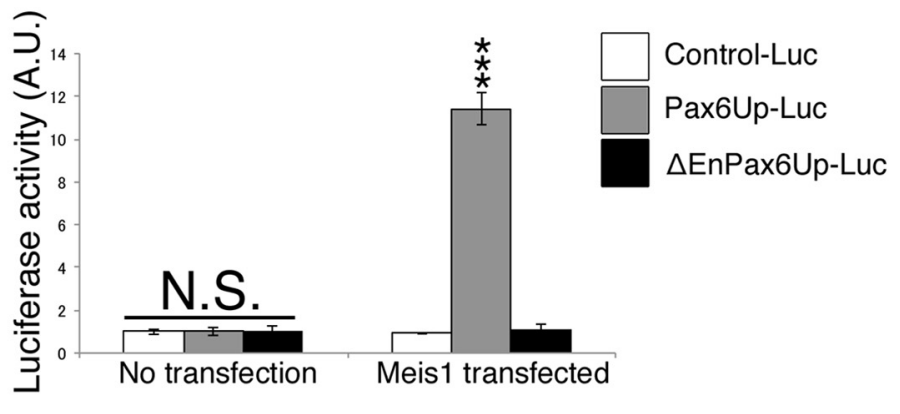

C

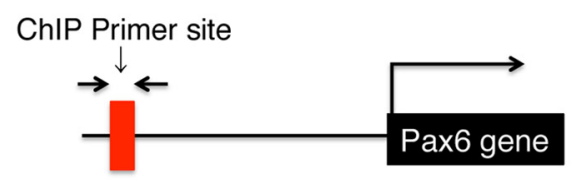

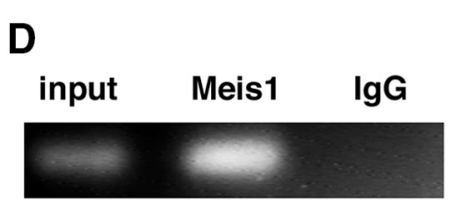

$\mathbf{E}$

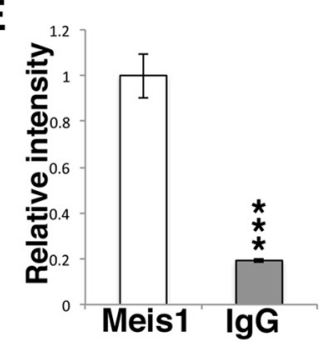

Figure 6. Regulation of Pax 6 transcription by Meis1. $\boldsymbol{A}$, Schematic of the $5^{\prime}$ upstream sequence of the Pax 6 gene and three reporter plasmids. $\boldsymbol{B}$, Luciferase activities of the reporter constructs in Neuro2a cells. $n=3$ cultures. $\boldsymbol{C}$, Schematic of positions of primer pairs used for the ChIP assay. D, E, ChIP assays revealing interaction of Meis 1 protein with the Meis 1 binding consensus region (red boxes in $\boldsymbol{A}$ and $\boldsymbol{C}$ ) of the Pax6 gene in purified GCPs. $n=6$ mice. Data are shown as mean \pm SEM. ${ }^{* * *} p<0.001$, Student's $t$ test.

well aligned in the homozygous cerebella at P10 and P21 (Fig. $8 C, D, G, H)$. The morphology of Bergmann glia/astrocytes and GABAergic interneurons in the ML were not greatly affected, as visualized with GFAP and parvalbumin, respectively, in the $\mathrm{KO}$ cerebella at these stages (Fig. $8 E, F, I-L$ ).

To examine the extent of apoptosis in the mutant cerebella at P10, we immunostained with active caspase 3 (an apoptosis marker), but observed no significant difference in the numbers of apoptotic cells between WT and cKO cerebella (Fig. 8M-O). This suggests that Meis1 is not involved in cell survival of GCPs/GCs.

We next examined the $\mathrm{KO}$ cerebella by immunostaining with several GC markers at P10. The thickness of EGL as deduced from the DAPI signals was significantly reduced in the Meis $1 \mathrm{cKO}$ mice (Fig. 9A-O). In addition, Pax6 expression was entirely lost in the mutant cerebella (Fig. 9A,B), as observed in the knock-down experiments (Fig. $4 H, I$ ), confirming that Meis1 is required for Pax6 expression in GCPs/GCs. Because several markers for GC lineage such as L1 (Fig. 8B), Atoh1, and NeuN (described below) were still observed in the cKO cerebella, it appears that the GCs retain their identity in the absence of Meis1 despite their loss of Pax6 expression. This is also supported by our observation of many GC-like cells by Nissl staining (Fig. 7H-O).

In the WT cerebella at P10, Atoh1 is expressed in GCPs in the outer EGL, which are known to proliferate actively (Fig. 9C,E, Flora et al., 2009) and include many mitotic (Ki67-positive) cells (Fig. 9G,I). In contrast, NeuN is expressed in postmitotic GCs in the inner EGL, ML, and IGL of the WT cerebella (Fig. $9 \mathrm{~K}, \mathrm{M}$; Weyer et al., 2003). In the cKO mice at P10, the EGL was largely populated by Atoh1-positive GCPs (Fig. 9D,F). Consistently, the EGL was also largely populated by Ki67-positive GCPs (Fig. $9 H, J)$, which was confirmed statistically by calculating the percentages of Atoh1-positive and Ki67-positive cells in the EGL (Fig. 9P,Q). This suggests that the cessation of Atoh1 expression and the cell cycle exit of GCPs in the inner EGL were delayed in the absence of Meis1. In contrast, NeuN-positive cells were rarely observed in the EGL and decreased in the ML (Fig. 9L, $N, R$ ), suggesting that differentiation of GCs was delayed in the $\mathrm{cKO}$ cerebella.

\section{Cell cycle exit is delayed in GCPs of cKO cerebella}

Next, we examined the cell cycle exit ratios of GCPs in the developing postnatal cerebellum. Brain sections at P10 were prepared $24 \mathrm{~h}$ after pulse labeling with BrdU and then immunostained with Ki67 (Fig. 10A-D). The number of cells that exited from the cell cycle $24 \mathrm{~h}$ after BrdU incorporation was estimated by quantifying the BrdU-positive and Ki67-negative cells over total BrdUpositive cells. In this experimental condition, the cell cycle exit ratio of GCPs was $36.0 \pm 5.0 \%$ in the EGL of P10 control cerebella. However, that ratio was reduced to $10.3 \pm 2.64 \%$ in the EGL of Meis 1 cKO homozygous mice (Fig. 10E). This result suggests that Meis1 positively regulates the cell cycle exit of GCPs in the EGL. Loss of Meis1 results in the delay of its timing and leads to the occupancy of the EGL with mitotic cells. We also found mitotic ectopic GCP clusters (Ki67 and/or Atoh1 positive) in the deeper region (Fig. 9D,F,H,J). The cell cycle exit ratio of these ectopic GCP clusters was $9.68 \pm 1.93 \%$ (Fig. 10E), indicating that the nature of these cells was similar to that of GCPs in the cKO EGL. Because Atoh1 was still expressed in these cells in the inner EGL and in the ML and because Atoh1 is suggested to promote cell cycle progression in GCPs (Flora et al., 2009), prolonged expression of Atoh1 may account for the delayed cell cycle exit in the cKO cerebella.

Next, to estimate proliferation of GCPs, we performed doubleimmunostaining with Ki67 and phospho-Histone H3 (a M-phase marker) to WT and cKO cerebella at P10 (Fig. 10 F, G). The number of $\mathrm{pH} 3$-positive cells was reduced in the Meisl cKO mice (Fig. 10H). Conversely, cells in the mitotic state (Ki67positive cells) were increased in the cKO mice (Fig. 10I) because of the inward expansion of mitotic cells (Fig. 10G), as can be observed in Figure 9, $H, J$, and $Q$. We calculated the ratio of M-phase ( $\mathrm{pH} 3$-positive) cells in the Ki67-positive cells and found that the ratio was severely reduced in the mutants (Fig. 10J). 

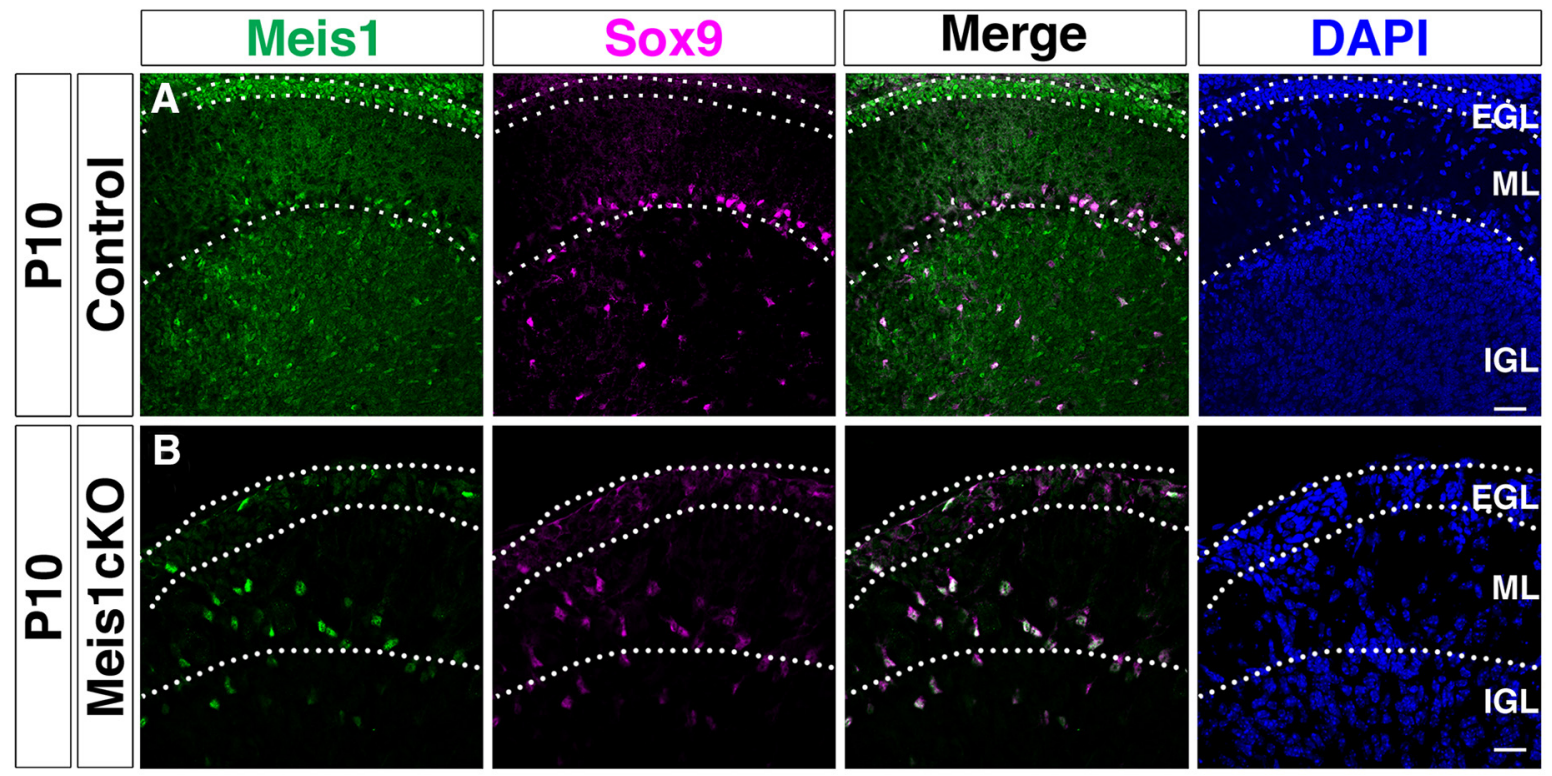

GL

$\mathbf{L}$

GL

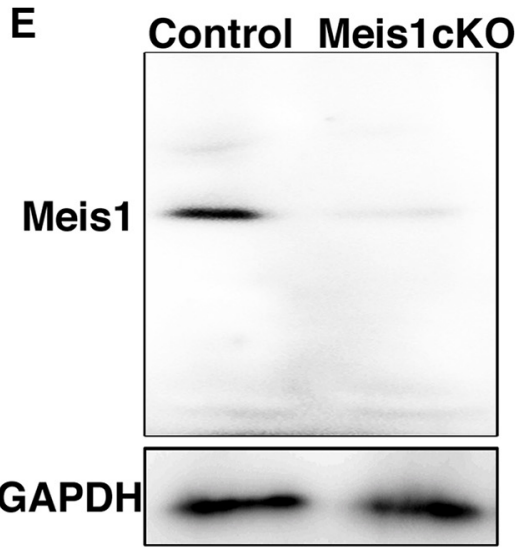

GCPs


Figure 7. Cerebellar structure is disrupted in the Meis $1 \mathrm{CKO}$ mice. $\boldsymbol{A}, \boldsymbol{B}$, Immunostaining with Meis 1 and Sox9 in cerebellar sagittal sections of control and Meis 1 cK0 mice at P10. Cell nuclei are visualized with DAPI. C, $\boldsymbol{D}$, Relative fluorescence intensities of Meis1 in Sox9-negative $(\boldsymbol{C})$ and Sox9-positive cells $(\boldsymbol{D})$ of control and Meis 1 cK0 cerebella. $n=3$ mice, 45 cells for each genotype $\boldsymbol{E}$, Immunoblot analysis with Meis1 in GCPs purified from control and Meis1 cK0 cerebella at P6. F, G, Dorsal view of whole brains of WT (F) and Meis1 cK0 (G) mice at P21. Red lines demarcate the hemispheres and the vermis of the cerebellum. $\boldsymbol{H}, \boldsymbol{I}$, Nissl staining of sagittal sections of cerebella from WT $(\boldsymbol{H})$ and Meis 1 CKO $(\boldsymbol{I})$ mice at P10. $\boldsymbol{J}, \boldsymbol{K}$, High magnification of the boxed region in $\boldsymbol{H}$ and I. $L, M$, Niss I staining of sagittal sections of the cerebella of WT $(\boldsymbol{L})$ and Meis $7 \mathrm{CKO}(\boldsymbol{M})$ mice at P21. $\boldsymbol{N}, \mathbf{O}$, High-magnification of the boxed region in $\boldsymbol{L}$ and $M$. Arrowheads indicate cell bodies of Purkinje cells that are not aligned. Scale bars: $\boldsymbol{A}, \boldsymbol{B}, \boldsymbol{J}, \boldsymbol{K}, \boldsymbol{N}, \mathbf{O}, 20 \mu \mathrm{m} ; \boldsymbol{H}, \boldsymbol{I}, \boldsymbol{L}, \boldsymbol{M}, 200 \mu \mathrm{m}$. Data are shown as mean \pm SEM. ${ }^{* * *} p<0.001$, Student's $t$ test. 

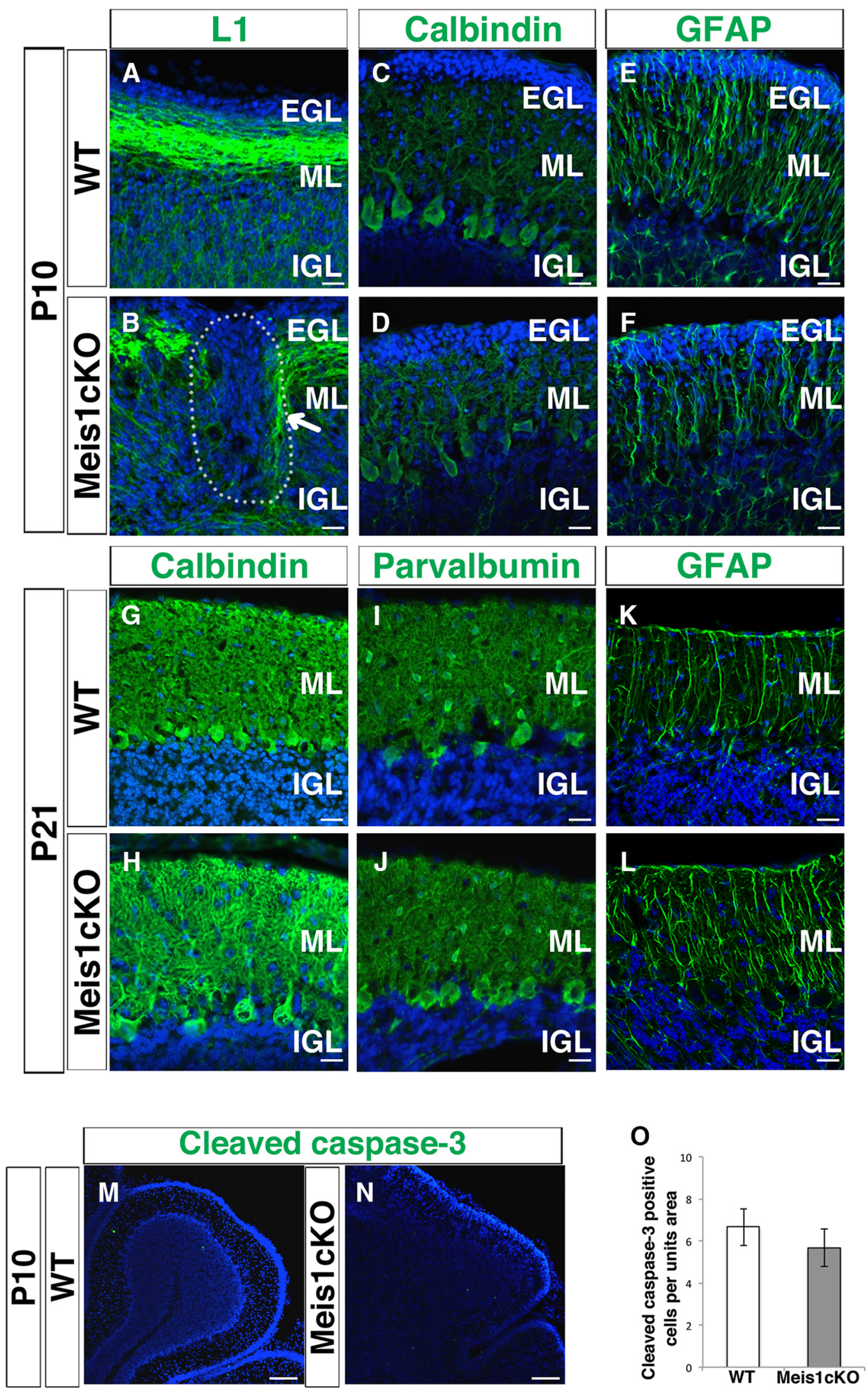

Figure 8. Immunohistochemical analyses of Meis $1 \mathrm{CKO}$ cerebella. $\boldsymbol{A}-\boldsymbol{L}$, Immunostaining with indicated antibodies and DAPI (blue) to cerebellar sections from WT (A, $C, E, G, I, K)$ and Meis 7 CKO $(\boldsymbol{B}, \boldsymbol{D}, \boldsymbol{F}, \boldsymbol{H}, \boldsymbol{J}, \boldsymbol{L})$ mice at P10 $(\boldsymbol{A}-\boldsymbol{F})$ and P21 $(\boldsymbol{G}-\boldsymbol{L})$. Arrow in $\boldsymbol{B}$ indicates disorganized parallel fibers. Dotted line in $\boldsymbol{B}$ indicates abnormal clustered cells at the curving point of the parallel fibers. These abnormal parallel fiber morphologies were found at $\sim 12$ sites per sagittal section along the midline. $\boldsymbol{M}, \boldsymbol{N}$, Immunostaining with cleaved caspase-3, a marker for apoptotic cells, in the cerebellar sections. Genotypes and developmental stages are indicated. $\mathbf{O}$, Quantification of apoptotic cells. $n=4$ mice, 12 slices for each genotype. Scale bars: $A-L, 20 \mu \mathrm{m} ; \boldsymbol{M}, \boldsymbol{N}, 100 \mu \mathrm{m}$. Data are shown as mean \pm SEM. $p>0.05$, Student's $t$ test. 

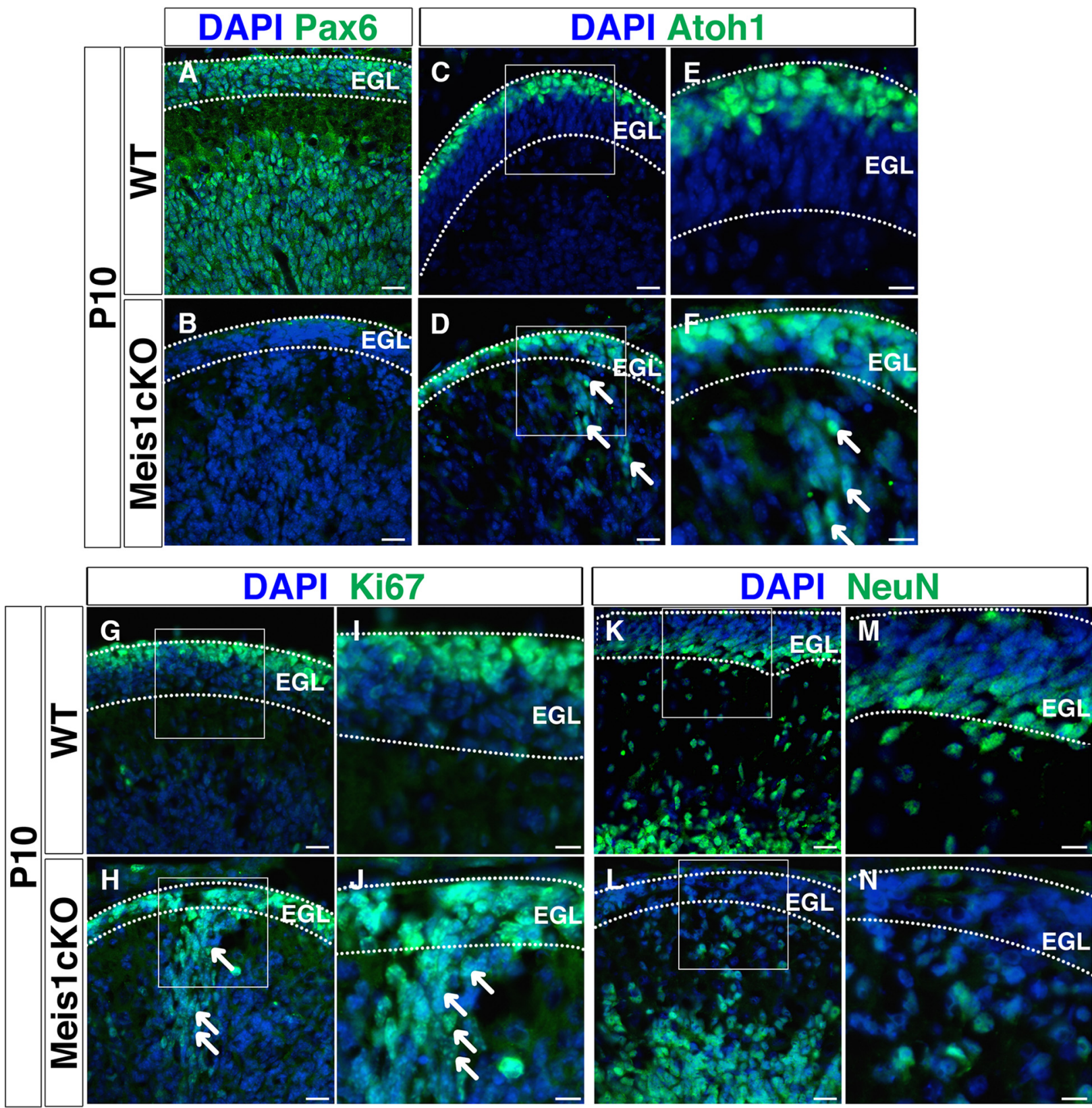

0

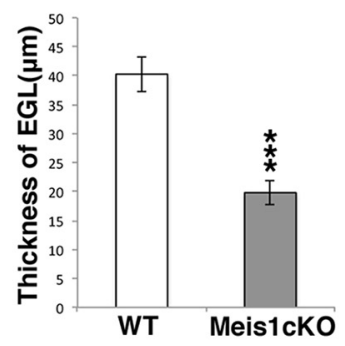

$\mathbf{P}$

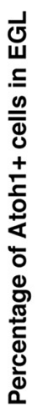

Q



$\mathbf{R}$

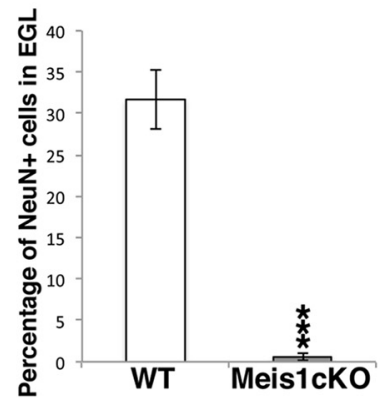

Figure 9. GC differentiation is disorganized in Meis 1 KO cerebella. $\boldsymbol{A}-\boldsymbol{N}$, Immunostaining with indicated antibodies in cerebellar sagittal sections from WT $(\boldsymbol{A}, \boldsymbol{C}, \boldsymbol{E}, \boldsymbol{G}, \boldsymbol{I}, \boldsymbol{K}, \boldsymbol{M})$ and $M e i s 7 \mathrm{CKO}(\boldsymbol{B}$, $D, F, H, J, L, N)$ mice at P10. Cell nuclei were visualized with DAPI. $E, F, I, J, M$, and $\boldsymbol{N}$, High-magnification of the boxed region in $C, D, G, H, K$, and $\boldsymbol{L}$, respectively. Arrows indicate ectopically localized GCPs that are positive for Atoh1 and Ki67. Approximately four or five ectopic clusters of proliferating cells $(\boldsymbol{D}, \boldsymbol{F}, \boldsymbol{H}, \boldsymbol{J})$ were observed per sagittal section along the midline. $\boldsymbol{O}$, EGL thickness of WT and cK0 cerebella. $n=4$ mice for each genotype. $\boldsymbol{P}-\boldsymbol{R}$, Percentages of Atoh1-positive cells $(\boldsymbol{P})$, Ki67-positive cells $(\boldsymbol{Q})$, and NeuN-positive cells $(\boldsymbol{R})$ in the EGL of WT and cK0 cerebella. $n=4$ mice, 12 slices for each genotype. Scale bars: $\boldsymbol{A}-\boldsymbol{D}, \boldsymbol{G}, \boldsymbol{H}, \boldsymbol{K}, \boldsymbol{L}, 20 \mu \mathrm{m} ; \boldsymbol{E}, \boldsymbol{F}, \boldsymbol{I}, \boldsymbol{J}, \boldsymbol{M}$, and $\boldsymbol{N}, 10 \mu \mathrm{m}$. Data are shown as mean \pm SEM. ${ }^{* * *} p<0.001$, Student's $t$ test. 


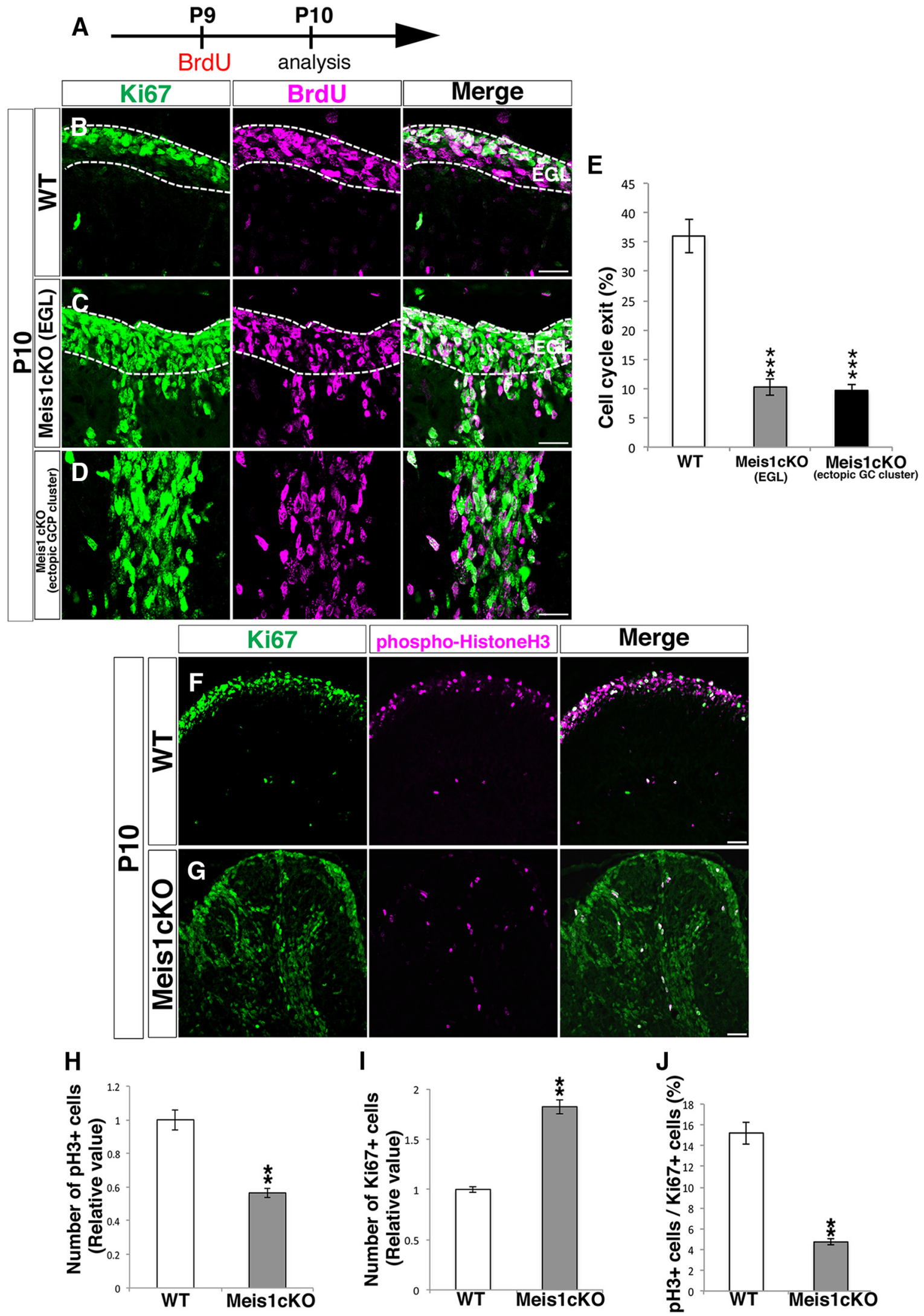

Figure 10. Cell cycle exit in Meis7 cKO cerebella. A, Schedule for the cell cycle exit assay at P10. B-D, Immunostaining with Ki67 and BrdU of cerebellar sections from WT and Meis7 cK0. E, Ratios of BrdU-positive and Ki67-negative cells over total BrdU-positive cells, which represent the cell cycle exit ratios at P10.n=3 mice, 10 slices for each genotype. $F, G$, Immunostaining with Ki67 and phospho-histone H3 of cerebellar sections from WT $(\boldsymbol{F})$ and Meis 1 cKO $(\boldsymbol{G})$ mice at P10. $\boldsymbol{H}, \boldsymbol{I}$, Quantification of phospho-histone H3-positive $(\boldsymbol{H})$ and Ki67-positive $(\boldsymbol{I})$ cells. $n=3$ mice, 10 slices for each genotype.J, Ratios of phospho-histone H3 and Ki67 double-positive cells over total Ki67-positive cells. $n=3$ mice, 10 slices for each genotype. Scale bars, $20 \mu \mathrm{m}$. Data are shown as mean \pm SEM. ${ }^{* *} p<0.01 ;{ }^{* * *} p<0.001$, Student's $t$ test. 

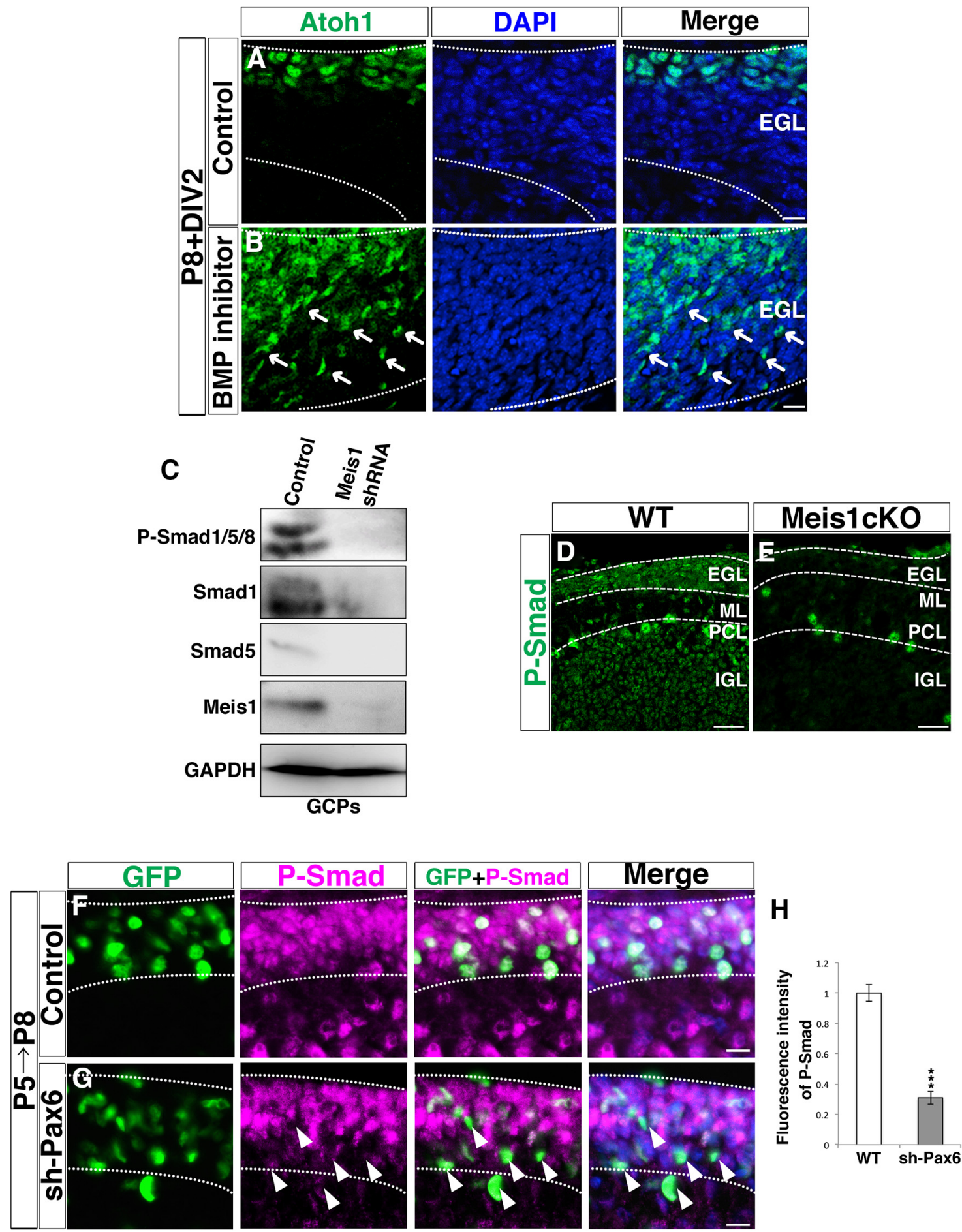

Figure 11. Meis1 affects BMP signaling. $A, B$, Immunostaining with Atoh1 in cultured cerebellar sagittal slices from P8 WT mice that were treated with control or $5 \mathrm{~nm}$ LDN-193189 (a BMP inhibitor) for $48 \mathrm{~h}$. C, Immunoblot analyses with indicated antibodies on purified GCPs transfected with control or sh-Meis 1 that were cultured for $24 \mathrm{~h}$ in the presence of $100 \mathrm{ng} / \mathrm{ml}$ BMP4. D, $\boldsymbol{E}$, Immunostaining with phospho-Smad1/5/8 (P-Smad) antibody in cerebellar sagittal sections from WT (D) or Meis 1 CKO (E) mice at P10. F, G, Immunostaining in P8 cerebellar sagittal sections with P-Smad antibody that were electroporated with control or sh-Pax6 at P5. Arrowheads indicate reduction of P-Smad fluorescence intensity in sh-Pax6 introduced cells. DAPI signals are shown in Nerge. $\boldsymbol{H}$, Relative value of P-Smad fluorescence intensity in GFP-positive cells. $n=3$ mice, 45 cells for each groups. Scale bars: $\boldsymbol{A}, \boldsymbol{B}, \boldsymbol{F}, \boldsymbol{G}, 10 \mu \mathrm{m}, \boldsymbol{D}, \boldsymbol{E}, 20 \mu \mathrm{m}$. Data are shown as mean \pm SEM. ${ }^{* * *} p<0.001$, Student's $t$ test.

These results suggest that, in the cKO mutants, proliferation of GCPs is much less active in the cKO cerebella than in WT even though more cells are in the cell cycle. This may cause the smaller cerebella in the mutant mice. Although we do not currently know how the loss of Meis1 leads to less activity in proliferation, it should be investigated in future studies.
Meis1 suppresses Atoh1 expression in GCs in the inner EGL via $\mathrm{BMP}$ signaling

It has been shown that mitotic GCPs are increased and differentiation of GCs is delayed in transgenic mice in which Atoh1 expression is upregulated in the GC lineage (Helms et al., 2000). This suggests that Meis1 accelerates cell cycle exit and differenti- 



Figure 12. BMP signaling and Meis1 in GC development. $A-C$, Immunostaining with GFP and P-Smad on P8 cerebella that were electroporated with indicated vectors at P5. D, Relative value of P-Smad fluorescence intensity in GFP-positive cells. $n=3$ mice, 45 cells for each groups. $\boldsymbol{E}$, Schematic model of the role of Meis 1 in the GC development. Scale bars in $\boldsymbol{A}-\boldsymbol{C}, 10 \mu \mathrm{m}$. Data are shown as mean \pm SEM. ${ }^{* * *} p<0.001$, Student's $t$ test.

ation of GCPs/GCs by suppressing the Atoh1 expression in the inner EGL. Therefore, the decreased cell cycle exit rate and delayed differentiation of GCPs/GCs may be caused by delayed cessation of Atoh1 expression in the Meis1 cKO cerebella.

It was shown previously that BMP4 treatment induces Atoh1 degradation in a proteasome-dependent manner in cultured dissociated GCPs (Zhao et al., 2008). Our immunostaining with phosphorylated Smad (phospho-Smad1/5/8) revealed that Smad signaling is active in various regions of the developing cerebellum, including the entire EGL at P10 (Fig. 11D). We administered LDN-193189, an inhibitor of BMP signaling, to slices of P8 WT cerebella, which were further cultured for $48 \mathrm{~h}$ and then examined. Although Atoh1 was expressed only in the outer EGL in control slices (Fig. 11A), its expression expanded downward into the entire EGL in the presence of LDN-193189 (arrows in Fig. $11 B)$, mimicking the phenotype observed in the Meisl cKO cerebella (Fig. 9D,F). This suggests that BMP signaling is involved in the cessation of Atoh1 expression in GCs in the inner EGL, contributing to their proper differentiation.

In the retina of zebrafish, it has been reported that Meis1 positively regulates BMP signaling via induction of Smad1 expression (Erickson et al., 2010). Because it is known that the cerebellum expresses Smad1 and Smad5, but rarely Smad8 (Rios et al., 2004), we suspected that Meis1 increases Smad1 and/or Smad5 expression in GCPs/GCs to enhance the BMP signaling pathway. To test this, we introduced sh-Meis1 to purified GCPs from P6 cerebella. As expected, Smad1 and Smad5 proteins and phosphorylated Smad (phospho-Smad1/5/8) were remarkably reduced even in the presence of BMP in the culture medium (Fig. 11C). Consistently, immunohistochemistry showed that Smad phosphorylation in small cells (putatively GCPs/GCs) was lost in the P10 Meis1 cKO cerebella (Fig. $11 D, E$ ), although strong phosphorylation signals in large cells (putatively Purkinje cells) were still detected. These findings indicate that BMP signaling is not activated in the GC lineage of the Meis 1 cKO mice and therefore suggest that, in WT mice, Meis1 is involved in BMP signaling via induction of Smad1 and Smad5 expression, which may lead to the cessation of Atoh1 expression in the inner EGL (Fig. 12E).

Next, we electroporated sh-Pax6 into cells in the WT EGL at P5 and observed Smad phosphorylation at P8 by immunostaining. Smad phosphorylation was significantly decreased by Pax6knock-down (Fig. 11F-H). Next, we coelectroporated sh-Meis1 with Pax6 or Smad1 into the WT EGL. The reduction of phosphorylated Smad by sh-Meis 1 was significantly rescued by cointroduction with Pax6 and Smad1, respectively (Figs. 11F, 12A-D), confirming that Pax6 and BMP signaling functions downstream of Meis1 (Fig. 12E).

\section{Discussion}

We showed that Meis1 is expressed in all GC lineage cells throughout developmental stages. Although Meis1 is also expressed in non-GCP/GC cells in the developing cerebellum, we focus on Meis1 function in GCPs/GCs in this study. 
We showed that Meis1 upregulates transcription of Pax6 in the developing cerebellum via binding to a Pax6 enhancer. It has been reported that processes from microexplants of Pax6 KO cerebellum exhibit twisted and lamellipodia-like morphology (Yamasaki et al., 2001). In our Pax6 knock-down experiments, we also observed abnormal morphology of migrating neurons as well as parallel fibers. In addition, ectopic clusters of $\mathrm{Pax}^{-1-}$ GCPs have previously been observed in the ML of $\mathrm{Pax6}^{-1-}$ and $\mathrm{Pax6}^{+/+}$chimeric cerebella (Swanson et al., 2011), mimicking the phenotype of Meis1 cKO cerebella. These findings suggest that the Meis1-Pax6 pathway is involved in the regulation of GC morphology and their process formation and migration.

The cKO cerebella exhibited disorganized structures at P21, when most of the cerebellar neurons should be arranged at appropriate positions. This suggests that Meis1 expression in the GC lineage is required for proper formation of the cerebellar structure. In the cKO cerebella during development, we observed ectopic clusters of mitotic GCPs in the ML that were Atoh1positive. Those cells migrate inwardly from the EGL before they exit from the cell cycle, indicating that the two important developmental processes, cell cycle exit and cell migration, can be distinct processes. That is, cell cycle exit and initiation of migration could be controlled by different molecular machineries. The ectopic GCPs in the mutant ML are proliferative and therefore may produce GCs, resulting in the disorganized lobules.

It was shown previously that administration of BMPs antagonized proliferation and induced differentiation of cultured GCPs by binding to their receptors, such as BMPR1a, BMPR1b, and BMPR2. The interaction of BMPs with their receptors leads to the phosphorylation of Smad proteins and then induces cell cycle exit of GCPs via the transcription of two basic helix-loop-helix (bHLH) proteins such as an inhibitor of DNA binding 1 (Id1) and Id2 (Rios et al., 2004; Zhao et al., 2008). In addition, Zhao et al. (2008) showed that administration of BMP to dissociated GCP cultures resulted in reduction of Atoh1 protein, which was inhibited by MG132, an inhibitor for proteasome-dependent protein degradation. In this study, we showed that administration of a BMP inhibitor to cultured cerebellar slices induced ectopically Atoh1-expressing GCPs even in the inner EGL. These observations suggest that BMP signaling induces protein degradation of Atoh1 in cultured GCPs as well as cerebellar tissue. Conversely, Forget et al. (2014) showed that an ubiquitin E3 ligase, Huwe1, is involved in Atoh1 degradation. However, administration of BMP to cultured GCPs purified from Huwel cKO mice still induced Atoh1 degradation, suggesting that Atoh1 is degraded through at least two distinct pathways, BMP-dependent and Huwe1-dependent pathways. As Meis1 is involved in BMP signaling in GCPs via upregulation of Smad proteins, Meis1 likely participates in the BMP-dependent pathway of Atoh1 degradation in the inner EGL.

We have to note that the Atoh1 expression is not suppressed in the upper part of the EGL even though Meis1 and phosphorylated Smad is also observed there. Although we do not know its underlying machinery, Atoh1 expression may be differentially regulated in GCPs/GCs in the upper and lower EGL. We suspect that the SHH signaling-dependent mechanisms might be involved in avoiding Atohl degradation because the signaling is only active in the outer EGL, not in the inner EGL.

BMP signaling is also reported to participate in cerebellar development at embryonic stages. At early neurogenesis stages, BMP6 and BMP7 are secreted from the choroid plexus to induce GCP production from the RL (Krizhanovsky and Ben-Arie, 2006). Consistent with this, targeted disruption of Smad1/Smad5 (Tong and Kwan, 2013) and Bmpr1a/Bmprlb (Qin et al., 2006) results in significant reduction of GCs due to reduced production of GCPs from the RL, but phenotypes at postnatal stages (after P0) were not reported. In this study, we show that Meis1 participates in BMP signaling to regulate GC development at postnatal stages.

Meis1 has been reported to play important roles in maintaining the undifferentiated state of hematopoietic stem cells, as shown by the observation that targeted disruption of Meis1 leads to depletion of hematopoietic stem cells (Hisa et al., 2004). Conversely, Meis1 has been linked to oncogenesis of leukemia (Lawrence et al., 1999; Imamura et al., 2002). Overexpression of Meis1 (in conjunction with Hoxa9) promotes transformation of hematopoietic stem cells into leukemic cells (Nakamura et al., 1996). Although Meis1 is also related to other tumors, such as neuroblastoma (Spieker et al., 2001; Geerts et al., 2003), a direct relationship between Meis1 and medulloblastoma, a tumor derived from GCPs, has not been reported. However, Meis1 expression is increased in a subset of medulloblastomas and some cell lines established from medulloblastomas (Jones et al., 2000; Robinson et al., 2012), suggesting that its misexpression may underlie the oncogenesis of medulloblastoma.

We found that Meis1 is required to form the proper overall structure of the cerebellum. We also found that Meis1 activates Pax6 transcription in GCPs/GCs and that this Meis1-Pax6 pathway regulates the cell cycle exit of GCPs in the inner EGL, maturation of GCs, and their subsequent formation of parallel fibers after leaving the EGL. The Meis1-Pax6 cascade is involved in BMP signaling in GCPs/GCs by inducing expression of Smad proteins, which leads to degradation of Atohl and differentiation of GCs from GCPs in the inner EGL.

This work should give insight into the molecular machinery for neural development, not only of the GCs, but also of other neurons in the nervous system. Moreover, this work may also help our understanding of oncogenesis, especially medulloblastoma. The function of Meis1 in Bergmann glia and astrocytes during cerebellar development remains unclear and requires future analyses.

\section{References}

Ariki R, Morikawa S, Mabuchi Y, Suzuki S, Nakatake M, Yoshioka K, Hidano S, Nakauchi H, Matsuzaki Y, Nakamura T, Goitsuka R (2014) Homeodomain transcription factor Meis1 is a critical regulator of adult bone marrow hematopoiesis. PLoS One 9:e87646. CrossRef Medline

Ayrault O, Zhao H, Zindy F, Qu C, Sherr CJ, Roussel MF (2010) Atoh1 inhibits neuronal differentiation and collaborates with Glil to generate medulloblastoma-initiating cells. Cancer Res 70:5618-5627. CrossRef Medline

Azcoitia V, Aracil M, Martínez AC, Torres M (2005) The homeodomain protein Meis1 is essential for definitive hematopoiesis and vascular patterning in the mouse embryo. Dev Biol 280:307-320. CrossRef Medline

Barber BA, Liyanage VR, Zachariah RM, Olson CO, Bailey MA, Rastegar M (2013) Dynamic expression of MEIS1 homeoprotein in E14.5 forebrain and differentiated forebrain-derived neural stem cells. Ann Anat 195: 431-440. CrossRef Medline

Butts T, Chaplin N, Wingate RJ (2011) Can clues from evolution unlock the molecular development of the cerebellum? Mol Neurobiol 43:67-76. CrossRef Medline

Contestabile A, Fila T, Bartesaghi R, Ciani E (2009) Cell cycle elongation impairs proliferation of cerebellar granule cell precursors in the Ts65Dn mouse, an animal model for Down syndrome. Brain Pathol 19:224-237. CrossRef Medline

Erickson T, French CR, Waskiewicz AJ (2010) Meis1 specifies positional information in the retina and tectum to organize the zebrafish visual system. Neural Dev 5:22. CrossRef Medline

Espinosa JS, Luo L (2008) Timing neurogenesis and differentiation: insights from quantitative clonal analyses of cerebellar granule cells. J Neurosci 28:2301-2312. CrossRef Medline

Fleming JT, He W, Hao C, Ketova T, Pan FC, Wright CC, Litingtung Y, 
Chiang C (2013) The Purkinje neuron acts as a central regulator of spatially and functionally distinct cerebellar precursors. Dev Cell 27:278292. CrossRef Medline

Flora A, Klisch TJ, Schuster G, Zoghbi HY (2009) Deletion of Atoh1 disrupts Sonic Hedgehog signaling in the developing cerebellum and prevents medulloblastoma. Science 326:1424-1427. CrossRef Medline

Forget A, Bihannic L, Cigna SM, Lefevre C, Remke M, Barnat M, Dodier S, Shirvani H, Mercier A, Mensah A, Garcia M, Humbert S, Taylor MD, Lasorella A, Ayrault O (2014) Shh signaling protects Atoh1 from degradation mediated by the E3 ubiquitin ligase Huwe1 in neural precursors. Dev Cell 29:649-661. CrossRef Medline

Fujiyama T, Yamada M, Terao M, Terashima T, Hioki H, Inoue YU, Inoue T, Masuyama N, Obata K, Yanagawa Y, Kawaguchi Y, Nabeshima Y, Hoshino M (2009) Inhibitory and excitatory subtypes of cochlear nucleus neurons are defined by distinct bHLH transcription factors, Ptfla and Atoh1. Development 136:2049-2058. CrossRef Medline

Geerts D, Schilderink N, Jorritsma G, Versteeg R (2003) The role of the MEIS homeobox genes in neuroblastoma. Cancer Lett 197:87-92. CrossRef Medline

Heine P, Dohle E, Bumsted-O’Brien K, Engelkamp D, Schulte D (2008) Evidence for an evolutionary conserved role of homothorax/Meis $1 / 2$ during vertebrate retina development. Development 135:805-811. CrossRef Medline

Helms AW, Abney AL, Ben-Arie N, Zoghbi HY, Johnson JE (2000) Autoregulation and multiple enhancers control Math1 expression in the developing nervous system. Development 127:1185-1196. Medline

Hirayama T, Asano Y, Iida H, Watanabe T, Nakamura T, Goitsuka R (2014) Meis1 is required for the maintenance of postnatal thymic epithelial cells. PLoS One 9:e89885. CrossRef Medline

Hisa T, Spence SE, Rachel RA, Fujita M, Nakamura T, Ward JM, DevorHenneman DE, Saiki Y, Kutsuna H, Tessarollo L, Jenkins NA, Copeland NG (2004) Hematopoietic, angiogenic and eye defects in Meis1 mutant animals. EMBO J 23:450 - 459. CrossRef Medline

Imamura T, Morimoto A, Takanashi M, Hibi S, Sugimoto T, Ishii E, Imashuku S (2002) Frequent co-expression of HoxA9 and Meis1 genes in infant acute lymphoblastic leukaemia with MLL rearrangement. Br J Haematol 119:119-121. CrossRef Medline

Jones TA, Flomen RH, Senger G, Nizetić D, Sheer D (2000) The homeobox gene MEIS1 is amplified in IMR-32 and highly expressed in other neuroblastoma cell lines. Eur J Cancer 36:2368-2374. CrossRef Medline

Kanda T, Sullivan KF, Wahl GM (1998) Histone-GFP fusion protein enables sensitive analysis of chromosome dynamics in living mammalian cells. Curr Biol 8:377-385. CrossRef Medline

Kawauchi T, Chihama K, Nabeshima Y, Hoshino M (2006) Cdk5 phosphorylates and stabilizes p27kip 1 contributing to actin organization and cortical neuronal migration. Nat Cell Biol 8:17-26. CrossRef Medline

Komuro H, Yacubova E (2003) Recent advances in cerebellar granule cell migration. Cell Mol Life Sci 60:1084-1098. CrossRef Medline

Krizhanovsky V, Ben-Arie N (2006) A novel role for the choroid plexus in BMP-mediated inhibition of differentiation of cerebellar neural progenitors. Mech Dev 123:67-75. CrossRef Medline

Lawrence HJ, Rozenfeld S, Cruz C, Matsukuma K, Kwong A, Kömüves L, Buchberg AM, Largman C (1999) Frequent co-expression of the HOXA9 and MEIS1 homeobox genes in human myeloid leukemias. Leukemia 13: 1993-1999. Medline

Lorenz A, Deutschmann M, Ahlfeld J, Prix C, Koch A, Smits R, Fodde R, Kretzschmar HA, Schüller U (2011) Severe alterations of cerebellar cortical development after constitutive activation of Wnt signaling in granule neuron precursors. Mol Cell Biol 31:3326-3338. CrossRef Medline

Morales D, Hatten ME (2006) Molecular markers of neuronal progenitors in the embryonic cerebellar anlage. J Neurosci 26:12226-12236. CrossRef Medline

Nakamura T, Largaespada DA, Shaughnessy JD Jr, Jenkins NA, Copeland NG (1996) Cooperative activation of Hoxa and Pbx1-related genes in murine myeloid leukaemias. Nat Genet 12:149-153. CrossRef Medline

Olmsted JB, Carlson K, Klebe R, Ruddle F, Rosenbaum J (1970) Isolation of microtubule protein from cultured mouse neuroblastoma cells. Proc Natl Acad Sci U S A 65:129-136. CrossRef Medline
Parmigiani E, Leto K, Rolando C, Figueres-Oñate M, López-Mascaraque L, Buffo A, Rossi F (2015) Heterogeneity and bipotency of astroglial-like cerebellar progenitors along the interneuron and glial lineages. J Neurosci 35:7388-7402. CrossRef Medline

Pompolo S, Harley VR (2001) Localisation of the SRY-related HMG box protein, SOX9, in rodent brain. Brain Res 906:143-148. CrossRef Medline

Qin L, Wine-Lee L, Ahn KJ, Crenshaw EB 3rd (2006) Genetic analyses demonstrate that bone morphogenetic protein signaling is required for embryonic cerebellar development. J Neurosci 26:1896-1905. CrossRef Medline

Rios I, Alvarez-Rodríguez R, Martí E, Pons S (2004) Bmp2 antagonizes sonic hedgehog-mediated proliferation of cerebellar granule neurones through Smad5 signalling. Development 131:3159-3168. CrossRef Medline

Robinson G, et al. (2012) Novel mutations target distinct subgroups of medulloblastoma. Nature 488:43-48. CrossRef Medline

Sotelo C (2004) Cellular and genetic regulation of the development of the cerebellar system. Prog Neurobiol 72:295-339. CrossRef Medline

Spieker N, van Sluis P, Beitsma M, Boon K, van Schaik BD, van Kampen AH, Caron H, Versteeg R (2001) The MEIS1 oncogene is highly expressed in neuroblastoma and amplified in cell line IMR32. Genomics 71:214-221. CrossRef Medline

Stedman A, Lecaudey V, Havis E, Anselme I, Wassef M, Gilardi-Hebenstreit P, Schneider-Maunoury S (2009) A functional interaction between Irx and Meis patterns the anterior hindbrain and activates krox20 expression in rhombomere 3. Dev Biol 327:566-577. CrossRef Medline

Stolt CC, Lommes P, Sock E, Chaboissier MC, Schedl A, Wegner M (2003) The Sox 9 transcription factor determines glial fate choice in the developing spinal cord. Genes Dev 17:1677-1689. CrossRef Medline

Swanson DJ, Goldowitz D (2011) Experimental Sey mouse chimeras reveal the developmental deficiencies of Pax6-null granule cells in the postnatal cerebellum. Dev Biol 351:1-12. CrossRef Medline

Tong KK, Kwan KM (2013) Common partner Smad-independent canonical bone morphogenetic protein signaling in the specification process of the anterior rhombic lip during cerebellum development. Mol Cell Biol 33:1925-1937. CrossRef Medline

Tucker ES, Lehtinen MK, Maynard T, Zirlinger M, Dulac C, Rawson N, Pevny L, Lamantia AS (2010) Proliferative and transcriptional identity of distinct classes of neural precursors in the mammalian olfactory epithelium. Development 137:2471-2481. CrossRef Medline

Vong KI, Leung CK, Behringer RR, Kwan KM (2015) Sox9 is critical for suppression of neurogenesis but not initiation of gliogenesis in the cerebellum. Mol Brain 8:25. CrossRef Medline

Wang VY, Zoghbi HY (2001) Genetic regulation of cerebellar development. Nat Rev Neurosci 2:484-491. CrossRef Medline

Weyer A, Schilling K (2003) Developmental and cell type-specific expression of the neuronal marker NeuN in the murine cerebellum. J Neurosci Res 73:400-409. CrossRef Medline

Williams SC, Altmann CR, Chow RL, Hemmati-Brivanlou A, Lang RA (1998) A highly conserved lens transcriptional control element from the Pax-6 gene. Mech Dev 73:225-229. CrossRef Medline

Yamada M, Seto Y, Taya S, Owa T, Inoue YU, Inoue T, Kawaguchi $\mathrm{Y}$, Nabeshima Y, Hoshino M (2014) Specification of spatial identities of cerebellar neuron progenitors by ptfla and atohl for proper production of GABAergic and glutamatergic neurons. J Neurosci 34:4786-4800. CrossRef Medline

Yamasaki T, Kawaji K, Ono K, Bito H, Hirano T, Osumi N, Kengaku M (2001) Pax6 regulates granule cell polarization during parallel fiber formation in the developing cerebellum. Development 128:3133-3144. Medline

Yu JY, DeRuiter SL, Turner DL (2002) RNA interference by expression of short-interfering RNAs and hairpin RNAs in mammalian cells. Proc Natl Acad Sci U S A 99:6047-6052. CrossRef Medline

Zhang X, Friedman A, Heaney S, Purcell P, Maas RL (2002) Meis homeoproteins directly regulate Pax6 during vertebrate lens morphogenesis. Genes Dev 16:2097-2107. CrossRef Medline

Zhao H, Ayrault O, Zindy F, Kim JH, Roussel MF (2008) Post-transcriptional down-regulation of Atoh1/Math1 by bone morphogenic proteins suppresses medulloblastoma development. Genes Dev 22:722-727. CrossRef Medline 